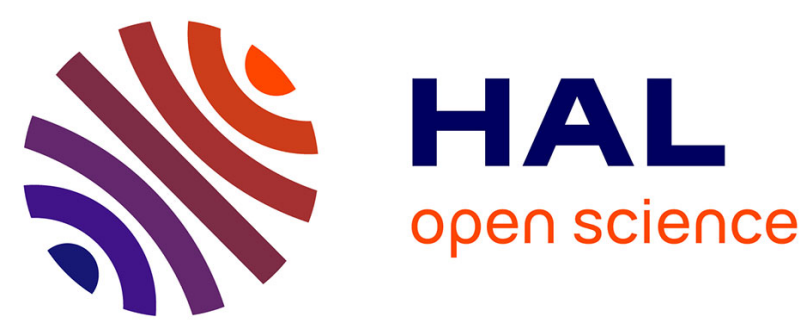

\title{
A Concise Synthesis of Oligosaccharides Derived From Lipoarabinomannan (LAM) with Glycosyl Donors Having a Nonparticipating Group at C2
}

Zhihao Li, Changping Zheng, Marco Terreni, Teodora Bavaro, Matthieu Sollogoub, Yongmin Zhang

\section{To cite this version:}

Zhihao Li, Changping Zheng, Marco Terreni, Teodora Bavaro, Matthieu Sollogoub, et al.. A Concise Synthesis of Oligosaccharides Derived From Lipoarabinomannan (LAM) with Glycosyl Donors Having a Nonparticipating Group at C2. European Journal of Organic Chemistry, In press, 10.1002/ejoc.201901915 . hal-02507462

\section{HAL Id: hal-02507462 https://hal.sorbonne-universite.fr/hal-02507462}

Submitted on 19 Mar 2020

HAL is a multi-disciplinary open access archive for the deposit and dissemination of scientific research documents, whether they are published or not. The documents may come from teaching and research institutions in France or abroad, or from public or private research centers.
L'archive ouverte pluridisciplinaire HAL, est destinée au dépôt et à la diffusion de documents scientifiques de niveau recherche, publiés ou non, émanant des établissements d'enseignement et de recherche français ou étrangers, des laboratoires publics ou privés. 


\section{A Concise Synthesis of Oligosaccharides Derived From}

Lipoarabinomannan (LAM) with Glycosyl Donors Having a Nonparticipating Group at C2

Zhihao LI, ${ }^{[\mathrm{a}]}$ Changping ZHENG, ${ }^{[\mathrm{a}]}$ Marco TERRENI, ${ }^{[\mathrm{b}]}$ Teodora BAVARO,${ }^{[\mathrm{b}]}$ Matthieu SOLLOGOUB, ${ }^{[a]}$ Yongmin ZHANG $^{[a], *}$

[a] Sorbonne Université, CNRS, Institut Parisien de Chimie Moléculaire, UMR 8232, 4 Place Jussieu, 75005 Paris, France

[b] University of Pavia, Drug Sciences Department, Viale Taramelli 12, 27100 Pavia, Italy

*Corresponding author E-mail: yongmin.zhang@upmc.fr

Abstract: Mycobacteria infection resulting in tuberculosis (TB) is one of the top ten leading causes of death over the world, and lipoarabinomannan (LAM) has been confirmed to play significant roles in this process. In this study, a convenient synthetic approach has been developed for the synthesis of oligosaccharides derived from LAM starting with commercially available substrates and reagents. The key steps for stereoselective construction of glycosidic bonds by acceptors glycosylated with donors without neighboring participating group were achieved. It's noteworthy that enzymatic hydrolysis was applied to prepare mannose building blocks and one step of birch reaction was used to deprotect acetyl and benzyl groups as well as reduce the azide group, which can avoid multiple chemical procedures. Finally, five oligosaccharides with terminal amino group at the anomeric substituent were furnished which could be used for conjugation with proteins as potential vaccines against TB.

Keywords: Carbohydrates • Lipoarabinomannan • Glycoconjugates • Glycosylation

Introduction 
As one of the top 10 causes of death worldwide in 2018, tuberculosis (TB) killed 1.5 million individuals including 251000 HIV affected cases. Although great effort has been made that 7 million people have received record levels of lifesaving TB treatment, lots of individuals still missed out ${ }^{[1]}$. Since the efficacy of drugs is limited by multiple drug resistance (MDR) and extensively-drug resistance (XDR), patients need to take a combination of three specific drugs to avoid the problem which is time and money consuming $^{[2]}$. So vaccine is still an ideal therapy fighting against TB. However, the only licensed vaccine BCG (Bacillus Calmette-Guérin) existing for 99 years is not effective enough, especially for the teenagers and adults ${ }^{[3]}$. It is essential to develop novel vaccines for TB prevention and immunotherapy.

Carbohydrates are one kind of complicated and diverse class of biomolecules commonly found in nature playing important roles in a multitude of biological processes and a series of pharmaceuticals and vaccines are based on carbohydrates ${ }^{[4]}$. As the major component in the cell wall of mycobacterium, lipoarabinomannan (LAM), a polysaccharide, has been attracting researchers' interests. Its structure is well-established containing an $\alpha-1,6$-and $\alpha-1,2$-linked mannan backbone, in which contains an arabinan domain containing an $\alpha-1,5$-linked $D$-arabinofuranosyl chain ${ }^{[2 a, 5]}$.

Due to the significant role of LAM in mycobacterium infection, nowadays researchers have paid much attention to LAM based vaccine and got some positive results ${ }^{[6]}$. However, it is extremely difficult to synthesize the LAM using the current technology due to its complicated structure, therefore studying its simplified analogues or derivatives is becoming a matter of research. Recently, a series of works on LAM mimetic synthesis have been reported. Bundle et al. succeeded in synthesizing three oligosaccharides, after conjugating them to the polymers, the conjugates displayed great characteristics for assay of antibody ${ }^{[7]}$. Guo et al. prepared several oligosaccharides as candidates for protein conjugation with decent biological activity and they concluded the oligosaccharide part is important for the activity ${ }^{[8]}$. Wattanasiri et al. synthesized LAM mimetic polysaccharide using rapid synthetic approach and evaluated its immunological properties with positive results $^{[9]}$. Bavaro et al. used monosaccharide, disaccharide and trisaccharide to conjugate the TB protein and all the three glycoproteins showed certain activity ${ }^{[10]}$. Besides, several 
linkers have been reported to conjugate sugar with protein, polypeptide or other functional substances $^{[2 b, 11]}$ which is also helpful for LAM based research development. The glycoprotein as vaccine candidates has received considerable critical attention in this field.

Although LAM has been proved to play important roles in the process of mycobacterium tuberculosis (M.TB) infection, there is no obvious evidence to show which part is the core unit for the immunological activity. Since little work has been devoted to looking for the key section, the oligosaccharide fundamental study is crucial for the LAM-based vaccine. Besides, during the LAM synthesis study, highly stereoselective construction of glycosidic bond has always been regarded as a challenge.

In this study, we describe our efforts for the synthesis of a variety of oligosaccharides derived from LAM. The key steps for stereoselective construction of glycosidic bonds by acceptors glycosylated with donors without neighboring participant were achieved. In addition, enzymatic hydrolysis was used to prepare the mannose building blocks, and one step of birch reaction was used to deprotect acetyl and benzyl groups as well as reduce the azide group, avoiding redundant procedures. Finally, five oligosaccharides with terminal amino group at the anomeric substituent derived from LAM were successfully synthesized, as shown in Figure 1, which can be used to conjugate with protein as potential TB vaccines.

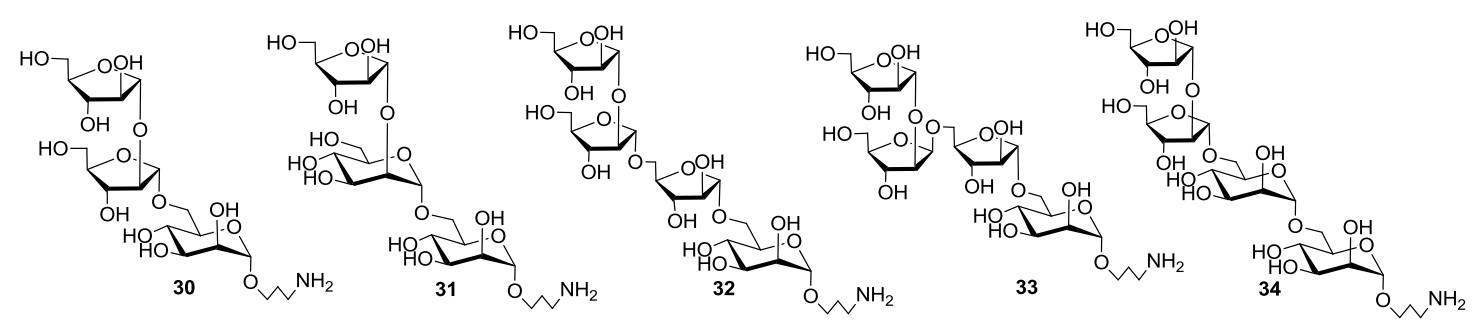

Figure 1. Five synthesized oligosaccharides

Results and Discussion

\section{Synthetic strategy analysis}


In this work, for the oligosaccharide construction, we directly adopted "Top to Bottom strategy", and "Bottom to Top strategy" was not tested. Taking targeted compound $\mathbf{3 0}$ in Figure 2A as an example, whether synthesizing from top to bottom or from bottom to top, it seems that both strategies have no significant difference. If using "Bottom to Top strategy", all the glycosylations will be carried out with donors having neighboring participant, which is helpful for stereoselectivity. However, applying "Top to Bottom strategy", the building block $\mathbf{C}$ can be easily prepared by enzymatic hydrolysis, avoiding redundant procedures. In addition, another example of oligosaccharide 32 shown in Figure 2B, "Top to Bottom with $3+1$ " strategy will be used. For " $3+1$ " strategy, the glycosylation between disaccharide donor I with no neighboring participant and monosaccharide acceptor $\mathbf{J}$ will be conducted, and if "2+2" strategy, the glycosylation between disaccharide donor $\mathbf{g}$ with no neighboring participant and disaccharide acceptor $\mathbf{h}$ will be conducted. For both strategies, avoiding isomer is still an issue during the glycosylation. 

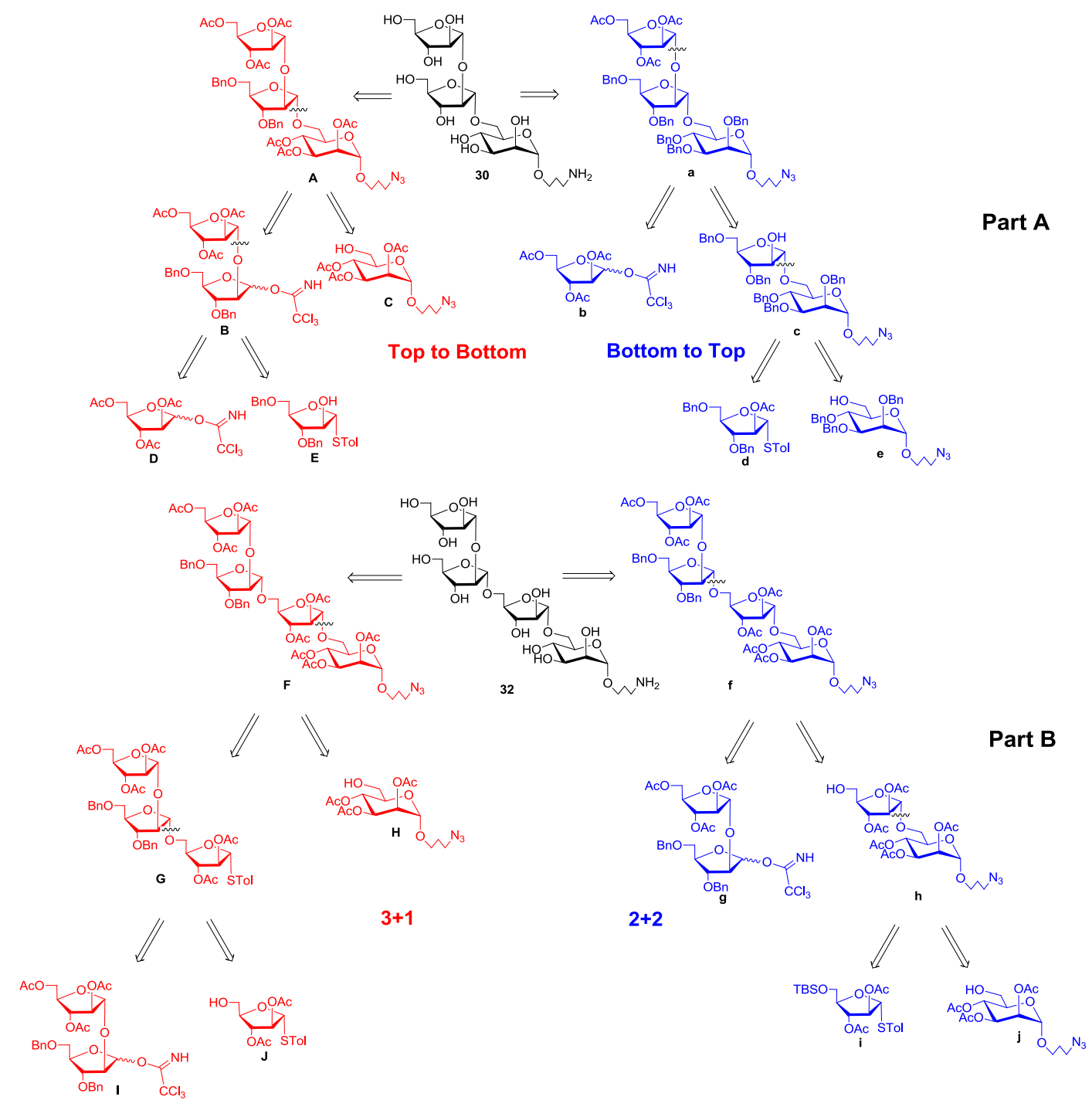

Figure 2. Comparison of retrosynthetic analysis for synthesizing trisaccharide $\mathbf{3 0}$ and tetrasaccharide $\mathbf{3 2}$ Taken "Top to Bottom" and "3+1" strategies, based on the retrosynthetic analysis, intermediates needed are shown in Figure $\mathbf{3}$ for synthesis of five protected oligosaccharides. At first, synthesis of compound $\mathbf{2 9}$ would start with disaccharide $\mathbf{2 6}$ and monosaccharide $\mathbf{9}$, while the disaccharide $\mathbf{2 6}$ is constructed by monosaccharide $\mathbf{3}$ and 23 . Next, for compound 12, except using monosaccharide $\mathbf{9}$, a different disaccharide $\mathbf{6}$ would be used which can be constructed by monosaccharide $\mathbf{3}$ and $\mathbf{5}$. Finally, for compound $\mathbf{2 1}$ and 22, applying " $3+1$ " strategy, trisaccharide 19, 20 and monosaccharide 9 are needed. And the trisaccharide 19 or $\mathbf{2 0}$ can be formed by disaccharide 6 and monosaccharide 18 with two different configurations. As for 15', trisaccharide 15 made by compound 6 and 13 as well as monosaccharide 9 need to be acquired as building blocks to finish the construction. 


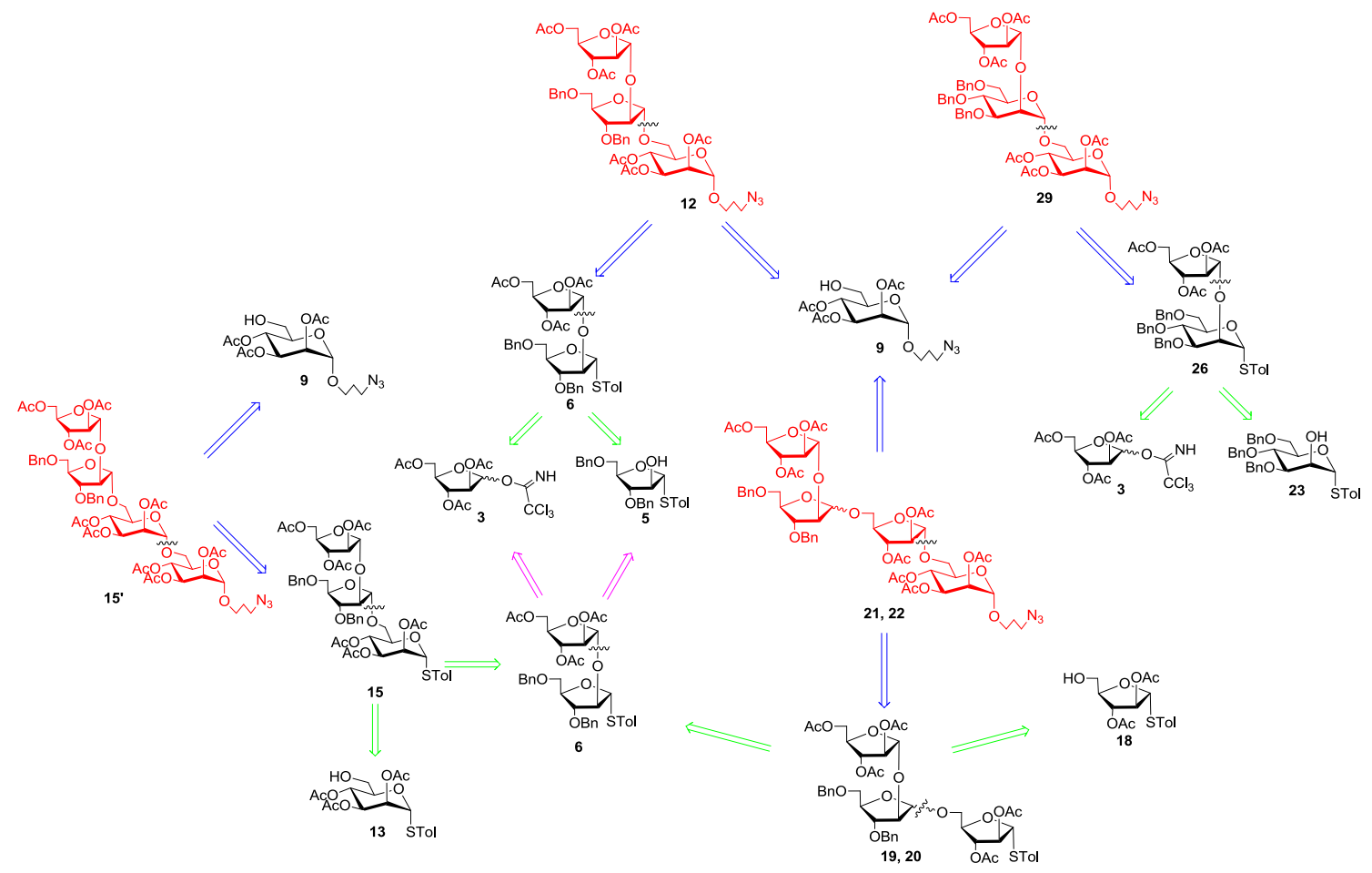

Figure 3. Retrosynthetic analysis for compound 12, 15', 21, 22 and 29

\section{Synthesis of oligosaccharides with neighboring nonparticipating arabinose donor}

As shown in Scheme 1, the synthesis started with commercially available D-arabinose 1. Since in the acetylation process of $D$-arabinose, it may transfer from furanose form to pyranose form, in order to obtain the peracetylated arabinose with furanose form $\mathbf{2}$, hydroxy group at C-1 or C-5 position always needs to be protected in advance. Although compound 2 was reported to be obtained directly by one step in the literature ${ }^{[12]}$, using the same method, furanose and pyranose mixture was obtained which was confirmed by ${ }^{13} \mathrm{C}$ NMR spectrum (see supporting information). So, in our hand, peracetylated arabinose 2 was synthesized by methyl glycoside intermediate, acetylation and anomeric acetylation from $\mathrm{D}$-arabinose for three steps $^{[13]}$. Then compound 2 was used to prepare the intermediate 3 by selectively anomeric acetyl deprotection and imidate introduction ${ }^{[14]}$. Meanwhile the known compound $\mathbf{4}$ was furnished by anomeric introduction of bromide, ortho-ester formation, acetyl deprotection, benzylation and anomeric p-methylphenyl thioglycoside (STol) introduction for five steps from the same starting material 2 according to the literature ${ }^{[8]}$. Next, the acetyl group at C-2 position in compound 4 was 
removed by Zemplén transesterification $\left(\mathrm{CH}_{3} \mathrm{ONa} / \mathrm{CH}_{3} \mathrm{OH}\right)$ to give the acceptor 5 . At last, a glycosylation between acceptor $\mathbf{5}$ and donor $\mathbf{3}$ was conducted to furnish disaccharide $\mathbf{6}$ in the yield of $86 \%$ at low temperature catalyzed by $\mathrm{BF}_{3} \cdot \mathrm{Et}_{2} \mathrm{O}$.

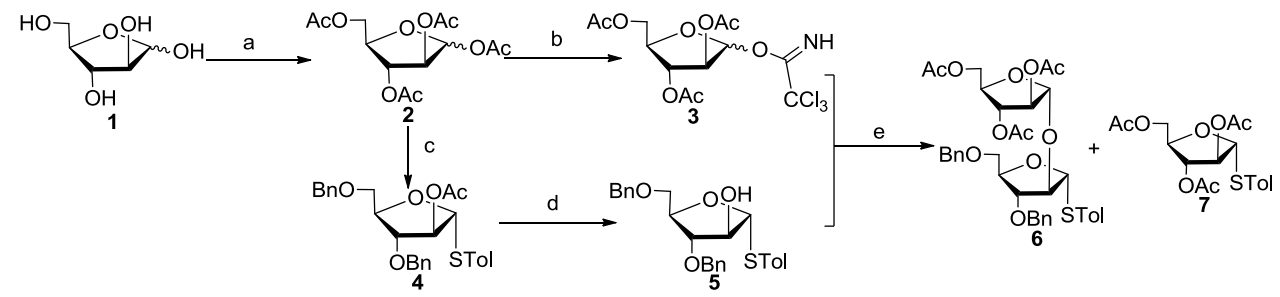

Scheme 1. Reagents and conditions: Transformations (a-c) have been conducted using reported protocols ${ }^{[8,13-14]}$; (d) $\mathrm{CH}_{3} \mathrm{OH}, \mathrm{CH}_{3} \mathrm{ONa}, \mathrm{RT}, 2 \mathrm{~h}, 96 \%$; (e) $\mathrm{BF}_{3} \cdot \mathrm{Et}_{2} \mathrm{O}, 4 \AA \mathrm{MS}, \mathrm{CH}_{2} \mathrm{Cl}_{2},-50{ }^{\circ} \mathrm{C}, 30 \mathrm{~min}, 86 \%$.

In the process of forming disaccharide $\mathbf{6}$, we found that reaction temperature has an effect on the ratio of byproduct $\mathbf{7}$, and low temperature can avoid the byproduct 7 . When the reaction was carried out at $0^{\circ} \mathrm{C}$, almost $2 / 3$ of product turned into 7 because the Lewis acid activated the STol group, and when the temperature reached $-10^{\circ} \mathrm{C}$ and $-30{ }^{\circ} \mathrm{C}$, the ratio dropped to $1 / 2$ and $1 / 3$, respectively. If temperature decreased to $-50{ }^{\circ} \mathrm{C}$ or lower, no byproduct 7 was found in ${ }^{1} \mathrm{H}$ NMR spectrum since the sulfur group is not activated at low temperature.

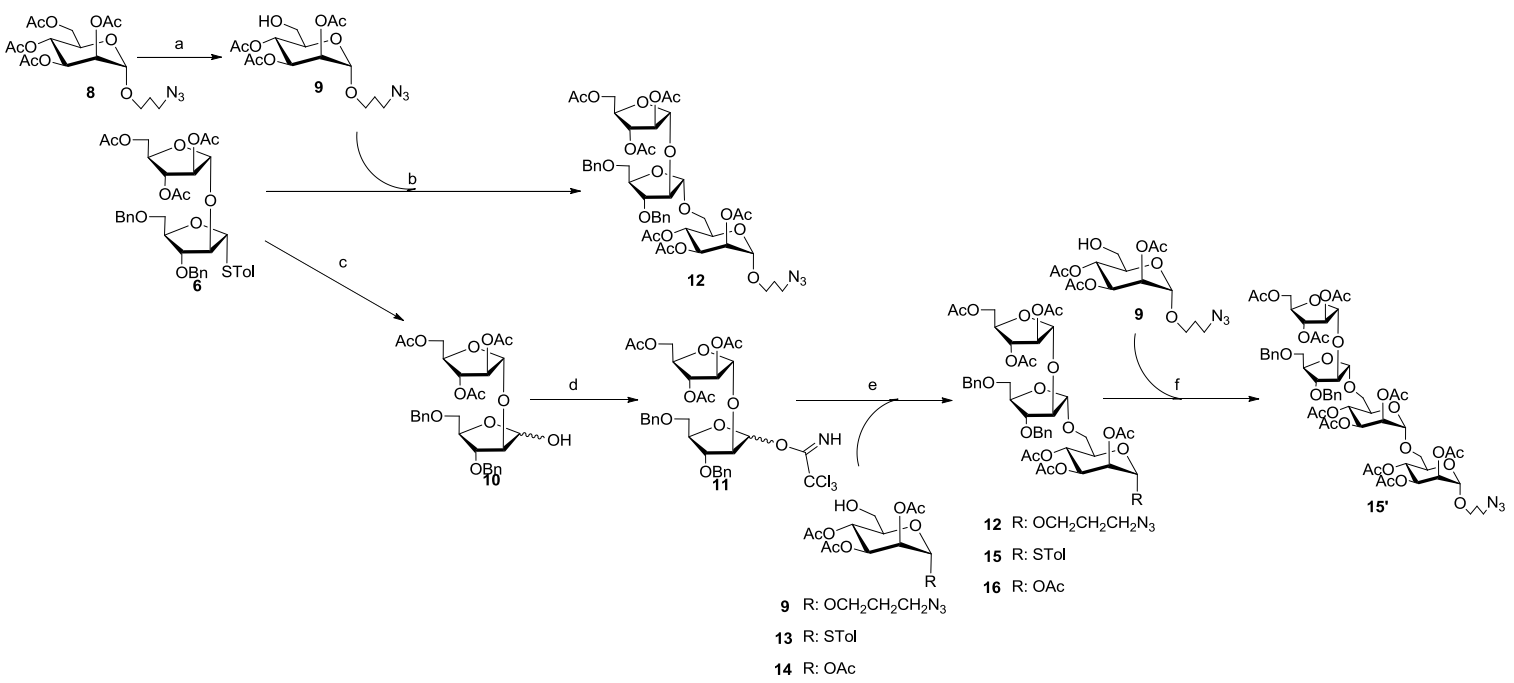

Scheme 2. Reagents and conditions: (a) immobilized CRL enzyme (1400 IU/g), acetonitrile, $\mathrm{KH}_{2} \mathrm{PO}_{4}, \mathrm{pH}$ = 4, RT, 24 h, 85\%; (b) NIS, AgOTf, $4 \AA ̊ \mathrm{MS}, \mathrm{CH}_{2} \mathrm{Cl}_{2},-10{ }^{\circ} \mathrm{C}, 30 \mathrm{~min}, 30 \%$; (c) NIS, AgOTf, TTBP, wet 
$\mathrm{CH}_{2} \mathrm{Cl}_{2}, 0^{\circ} \mathrm{C}-\mathrm{RT}, 1 \mathrm{~h}, 91 \%$; (d) $\mathrm{CCl}_{3} \mathrm{CN}, \mathrm{DBU}, \mathrm{CH}_{2} \mathrm{Cl}_{2}, 0{ }^{\circ} \mathrm{C}, 30 \mathrm{~min}, 90 \%$; (e) $\mathrm{BF}_{3} \cdot \mathrm{Et}_{2} \mathrm{O}, 4 \AA \mathrm{AS}, \mathrm{Et}_{2} \mathrm{O}$, $-30{ }^{\circ} \mathrm{C}, 1 \mathrm{~h}, 12$ ( $\left.69 \%\right), 15(60 \%), 16(65 \%)$, respectively.

In Scheme 2, mono-deprotected compound 9 bearing a free $\mathrm{C}-6 \mathrm{OH}$ was prepared by enzymatic hydrolysis from known compound $\mathbf{8}$ in high yield. In this step, the enzymatic hydrolysis was used to prepare building block 9, which can avoid multiple chemical procedures. The enzyme CRL can selectively remove the acetyl group at C-6 position of monosaccharides. Further, the glycosylation reaction was carried out between acceptor 9 and donor 6 to furnish the trisaccharide 12 by NIS/AgOTf as promoters in $\mathrm{CH}_{2} \mathrm{Cl}_{2}$. Due to no neighboring group participation during the glycosylation, isomers of $\alpha$ and $\beta$ (1:2) were formed. On the other hand, the STol group in disaccharide 6 was removed using NIS, AgOTf and 2,4,6-Tri-tert-butylpyrimidine (TTBP) in wet $\mathrm{CH}_{2} \mathrm{Cl}_{2}$ to get compound 10 with free hydroxy at the anomeric center and then intermediate $\mathbf{1 0}$ was transformed into trichloroacetimidate 11 at $0{ }^{\circ} \mathrm{C}$ with $\mathrm{CCl}_{3} \mathrm{CN}$ and $\mathrm{DBU}$. At last, the imidate 11 was used as donor to glycosylate with acceptor 9 using $\mathrm{BF}_{3} \cdot \mathrm{Et}_{2} \mathrm{O}$ catalyst in $\mathrm{Et}_{2} \mathrm{O}$ to obtain the trisaccharide 12 with good a selectivity successfully. We propose that $\mathrm{Et}_{2} \mathrm{O}$ firstly combined the anomeric carbon in donor $\mathbf{1 1}$ leading to more $\beta$ configuration product, and then the acceptor 9 attacked the intermediate from back with $\mathrm{Et}_{2} \mathrm{O}$ leaving, producing more a compound 12. Besides, the known compound 13 and 14 were synthesized by the similar enzymatic method with excellent yield and used as acceptor to furnish 15 and 16 in $\mathrm{Et}_{2} \mathrm{O}$. Next, in order to get $\mathbf{1 5}^{\prime}$ the glycosylation was tried between trisaccharide $\mathbf{1 5}$ and monosaccharide 11 by NIS and AgOTf. However, the formal promoter cannot remove the sulfur group in $15^{\prime}$ because of pyranose's poor activity as well as the disarming of acetyl. Fortunately, changing catalyst to NIS and TMSOTf can achieve the activation and 15' was formed with decent yield at low temperature.

In Scheme 3, compound 18 was synthesized from monosaccharide 17, which was obtained by $\mathrm{C}-5 \mathrm{OH}$ protection with TBS group and then acetylation. By adding $\mathrm{BF}_{3} \cdot \mathrm{Et}_{2} \mathrm{O}$ at $0^{\circ} \mathrm{C}$ to introduce the STol group at the anomeric center and deprotecting the TBS group at C-5 position was achieved in one step to prepare compound 18 with the yield of $66 \%$. With building blocks 11 and 18 in hand, the glycosylation was performed to furnish 
trisaccharide 19 and 20 using Lewis acid as promoter. The different configurations were confirmed by the ${ }^{13} \mathrm{C}$ NMR spectrum ${ }^{[2 b]}$, and the coupling constant for 19 was $105 \mathrm{ppm}$ and for $\mathbf{2 0}$ was $101 \mathrm{ppm}$. In this step, it needs the careful chromatography to separate them. Then catalyzed by NIS and AgOTf at $-10^{\circ} \mathrm{C}$, donors 19 and 20 were used directly to glycosylate acceptor 9 to furnish compounds 21 and 22 in excellent yields, respectively.
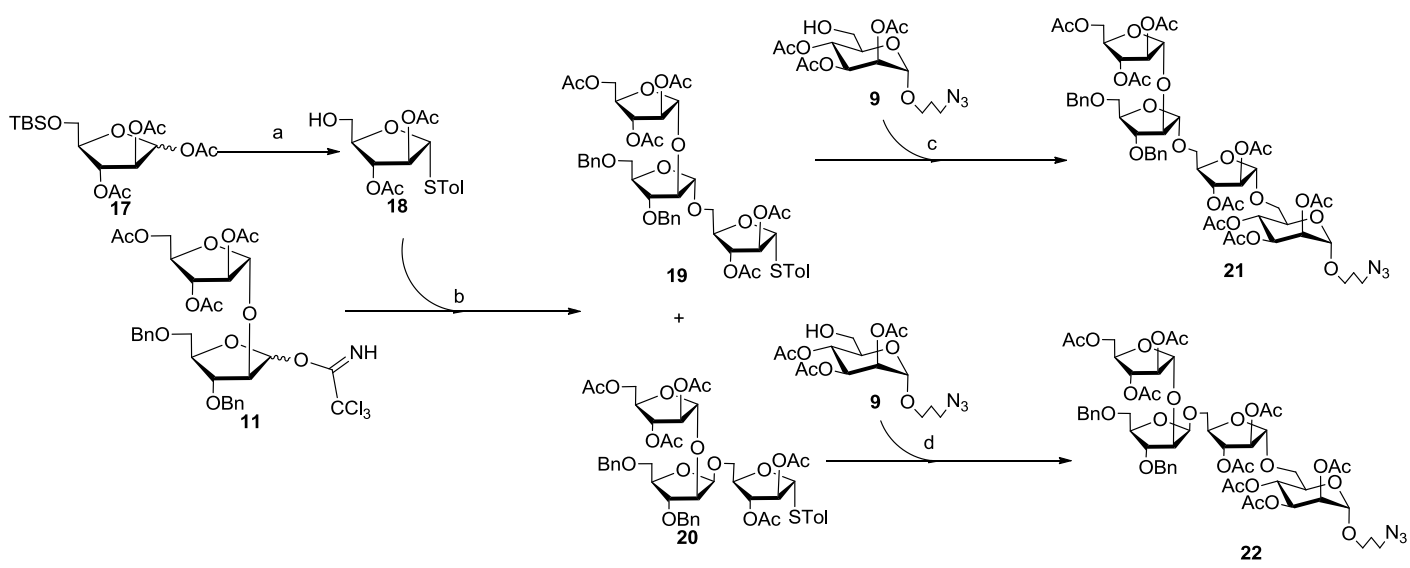

Scheme 3. Reagents and conditions: (a) thiocresol, $\mathrm{BF}_{3} \cdot \mathrm{Et}_{2} \mathrm{O}, \mathrm{CH}_{2} \mathrm{Cl}_{2}, 0{ }^{\circ} \mathrm{C}, 2 \mathrm{~h}, 66 \%$; (b) $\mathrm{BF}_{3} \cdot \mathrm{Et}_{2} \mathrm{O}, 4 \AA$ MS, Et $\mathrm{E}_{2} \mathrm{O}, 1 \mathrm{~h},-30^{\circ} \mathrm{C}, 19$ (58\%), 20 (29\%); (c) NIS, AgOTf, $4 \AA \mathrm{AS}, \mathrm{CH}_{2} \mathrm{Cl}_{2},-10^{\circ} \mathrm{C}, 30 \mathrm{~min}, 82 \%$; (d) NIS, AgOTf, $4 \AA \mathrm{MS}, \mathrm{CH}_{2} \mathrm{Cl}_{2},-10^{\circ} \mathrm{C}, 30 \mathrm{~min}, 84 \%$.

Table 1. Arabinose donors without neighbouring group participation for glycosylation

\begin{tabular}{cccccccc}
\hline Entry & Donor & Acceptor & Solvent & Catalyst & Temperature & Targeted Product & $\begin{array}{c}\text { Total Yield } \\
\text { (Ratio of } \alpha: \beta)\end{array}$ \\
\hline 1 & $\mathbf{6}$ & $\mathbf{9}$ & $\mathrm{CH}_{2} \mathrm{Cl}_{2}$ & $\mathrm{NIS}, \mathrm{AgOTf}$ & $-10{ }^{\circ} \mathrm{C}$ & $\mathbf{1 2}$ & $90 \%(1: 2)$ \\
2 & $\mathbf{6}$ & $\mathbf{9}$ & $\mathrm{CH}_{2} \mathrm{Cl}_{2}$ & $\mathrm{NIS}, \mathrm{AgOTf}, \mathrm{DMF}$ & $-30{ }^{\circ} \mathrm{C}$ & $\mathbf{1 2}$ & $40 \%(1: 1.8)$ \\
3 & $\mathbf{6}$ & $\mathbf{9}$ & $\mathrm{Et}_{2} \mathrm{O}$ & $\mathrm{NIS}, \mathrm{AgOTf}$ & $-10{ }^{\circ} \mathrm{C}$ & - & - \\
4 & $\mathbf{1 1}$ & $\mathbf{9}$ & $\mathrm{Et}_{2} \mathrm{O}$ & $\mathrm{BF}_{3} \cdot \mathrm{Et}_{2} \mathrm{O}$ & $-30{ }^{\circ} \mathrm{C}$ & $\mathbf{1 2}$ & $92 \%(3: 1)$ \\
5 & $\mathbf{1 1}$ & $\mathbf{1 3}$ & $\mathrm{Et}_{2} \mathrm{O}$ & $\mathrm{BF}_{3} \cdot \mathrm{Et}_{2} \mathrm{O}$ & $-30{ }^{\circ} \mathrm{C}$ & $\mathbf{1 5}$ & $80 \%(3: 1)$ \\
6 & $\mathbf{1 1}$ & $\mathbf{1 4}$ & $\mathrm{Et}_{2} \mathrm{O}$ & $\mathrm{BF}_{3} \cdot \mathrm{Et}_{2} \mathrm{O}$ & $-30{ }^{\circ} \mathrm{C}$ & $\mathbf{1 6}$ & $87 \%(3: 1)$ \\
7 & $\mathbf{1 1}$ & $\mathbf{1 8}$ & $\mathrm{Et}_{2} \mathrm{O}$ & $\mathrm{BF}_{3} \cdot \mathrm{Et}_{2} \mathrm{O}$ & $-30{ }^{\circ} \mathrm{C}$ & $\mathbf{1 9}$ & $88 \%(2: 1)$ \\
\hline
\end{tabular}

It's well known that donors with neighbouring group participation are always used for stereoselective construction of glycosidic bonds. In our work, the arabinose donor with 
neighboring nonparticipant was used for glycosylation, and glycosylations were studied and compared in Table 1. In entry 1, compound $\mathbf{6}$ was used as donor to directly react with acceptor 11, more $\beta$ isomer was obtained distinguished from the ${ }^{13} \mathrm{C}$ NMR spectrum. Since DMF may affect the configuration in pyranose donor according to the literature ${ }^{[15]}$, in the entry 2, DMF along with NIS/AgOTf as promoters were used at low temperature. However, it was seen that preactivating the donor with DMF added can slightly affect the isomer ratio, and the yield deceased obviously because the donor intermediate is activated that byproduct may appear before adding acceptor $\mathbf{9}$. Further in the entry $\mathbf{3}$, $\mathrm{Et}_{2} \mathrm{O}$ was used for donor $\mathbf{6}$ and acceptor 9 glycosylation with NIS/AgOTf as promoters. However, no reaction was observed due to the poor solubility and catalytic ability of promoters in $\mathrm{Et}_{2} \mathrm{O}$. Next, the donor imidate 11 with $\mathrm{BF}_{3} \cdot \mathrm{Et}_{2} \mathrm{O}$ as catalyst in the $\mathrm{Et}_{2} \mathrm{O}$ solvent (entry 4 ) at $-30^{\circ} \mathrm{C}$ produced more $\alpha$ than $\beta$ isomer with the ratio of $\alpha$ and $\beta$ 3:1. Then given the results of entry 5 and $\mathbf{6}$, compared with entry 4, different groups at C-1 position of the acceptors (13 and $\mathbf{1 4}$ ) did not affect isomer ratio too much. When acceptor 18 was used as donor to glycosylate 11 at the same temperature in $\mathrm{Et}_{2} \mathrm{O}$, the ratio changed in some degree, which indicated changing the acceptor from pyranose to furanose may affect isomer ratio (entry 7 ). 


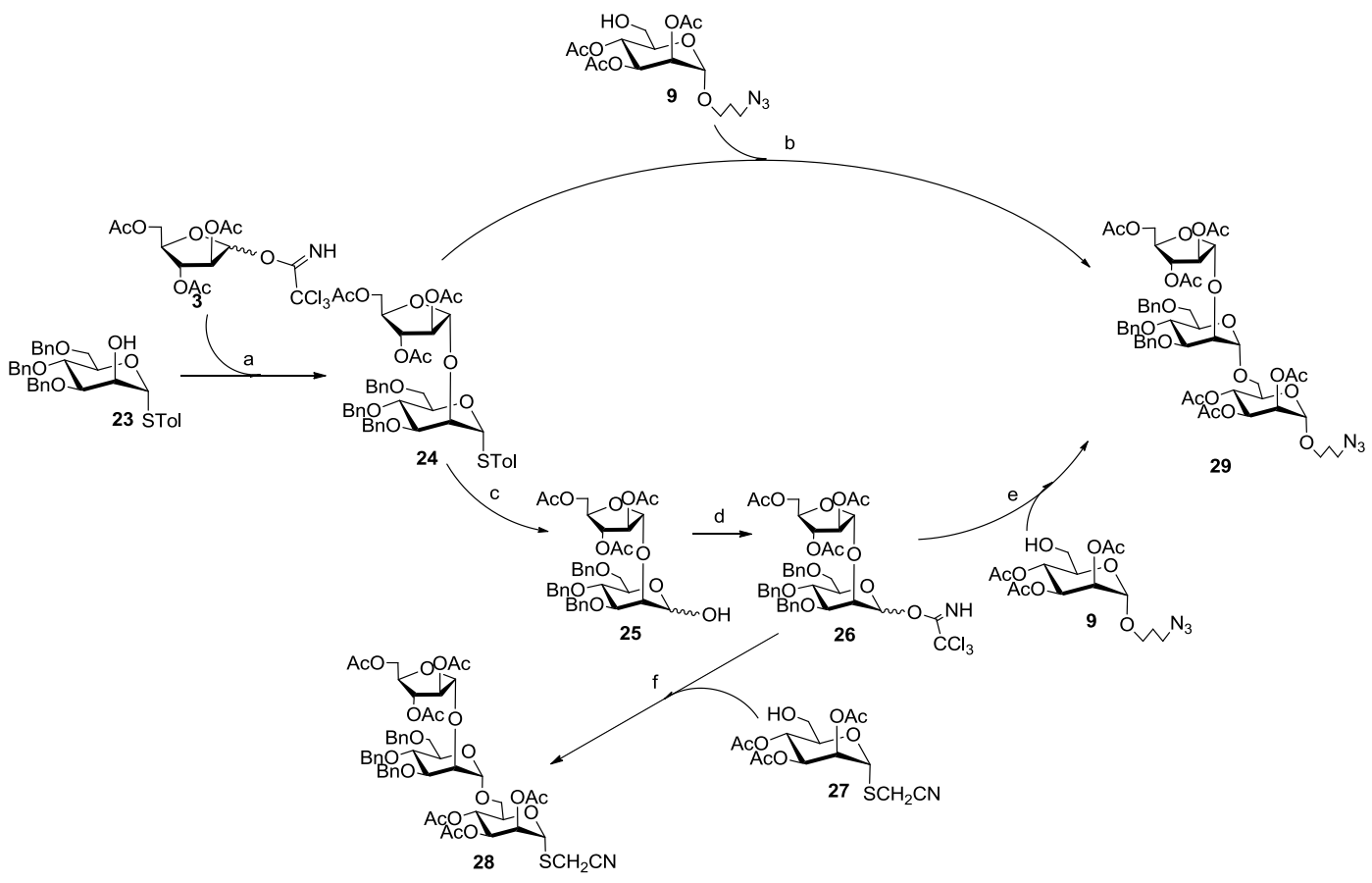

Scheme 4. Reagents and conditions: (a) $\mathrm{BF}_{3} \cdot \mathrm{Et}_{2} \mathrm{O}, 4 \AA \mathrm{MS}, \mathrm{CH}_{2} \mathrm{Cl}_{2},-50^{\circ} \mathrm{C}, 30 \mathrm{~min}, 90 \%$; (b) NIS, AgOTf, $4 \AA \mathrm{MS}, \mathrm{CH}_{2} \mathrm{Cl}_{2},-10^{\circ} \mathrm{C}, 30 \mathrm{~min}, 53 \%$; (c) NIS, AgOTf, TTBP, wet $\mathrm{CH}_{2} \mathrm{Cl}_{2}, 0{ }^{\circ} \mathrm{C}-\mathrm{RT}, 1 \mathrm{~h}, 85 \%$; (d) $\mathrm{CCl}_{3} \mathrm{CN}$, $\mathrm{DBU}, \mathrm{CH}_{2} \mathrm{Cl}_{2}, 0{ }^{\circ} \mathrm{C}, 1 \mathrm{~h}, 90 \%$; (e) $\mathrm{BF}_{3} \cdot \mathrm{Et}_{2} \mathrm{O}, 4 \AA \mathrm{MS}, \mathrm{Et}_{2} \mathrm{O},-30{ }^{\circ} \mathrm{C}, 3 \mathrm{~h}, 75 \%$; (f) $\mathrm{BF}_{3} \cdot \mathrm{Et}_{2} \mathrm{O}, 4 \AA \mathrm{MS}$, $\mathrm{Et}_{2} \mathrm{O}: \mathrm{CH}_{2} \mathrm{Cl}_{2}(15: 1),-30^{\circ} \mathrm{C}, 3 \mathrm{~h}, 45 \%$.

In Scheme 4, the known compound 23 was synthesized by 6 steps according to the literature ${ }^{[16]}$ and then it was taken as acceptor to furnish disaccharide $\mathbf{2 4}$ with donor $\mathbf{3}$ at low temperature using Lewis acid. Since STol is less reactive in mannose than arabinose, no byproduct was found when temperature changed. Then compound $\mathbf{2 4}$ was used as donor directly to glycosylate 9 by NIS/AgOTf at $-10^{\circ} \mathrm{C}$ to furnish trisaccharide 29 , where isomer mixture was obtained $(\alpha: \beta=2: 1)$. On the other hand, the STol group at C-1 position of 24 was removed by NIS, AgOTf and TTBP in wet $\mathrm{CH}_{2} \mathrm{Cl}_{2}$ to obtain intermediate $\mathbf{2 5}$ which was transformed into imidate 26. Surprisingly, when imidate $\mathbf{2 6}$ was used as donor to glycosylate acceptor 9 in $\mathrm{Et}_{2} \mathrm{O}$ for furnishing 29, pure $\alpha$ isomer was formed at low temperature with high yield.

In addition, building block 27 that was prepared by enzyme catalyst was also glycosylated with intermediate 26 to construct trisaccharide 28 using $\mathrm{BF}_{3} \cdot \mathrm{Et}_{2} \mathrm{O}$ at $-30^{\circ} \mathrm{C}$ in mixed solution of $\mathrm{Et}_{2} \mathrm{O}$ and $\mathrm{CH}_{2} \mathrm{Cl}_{2}(15: 1)$, because compound 27 is not well soluble in $\mathrm{Et}_{2} \mathrm{O}$. The pure $\alpha$ product was obtained with decent yield. 
Table 2. Mannose donor without neighbouring group participation for glycosylation

\begin{tabular}{cccccccc}
\hline Entry & Donor & Acceptor & Solvent & Catalyst & Temperature & $\begin{array}{c}\text { Targeted Product } \\
\text { Total Yield } \\
\text { Ratio of } \alpha: \beta)\end{array}$ \\
\hline 1 & $\mathbf{2 4}$ & $\mathbf{9}$ & $\mathrm{CH}_{2} \mathrm{Cl}_{2}$ & $\mathrm{NIS}, \mathrm{AgOTf}$ & $-10{ }^{\circ} \mathrm{C}$ & $\mathbf{2 9}$ & $80 \%(2: 1)$ \\
2 & $\mathbf{2 6}$ & $\mathbf{9}$ & $\mathrm{Et}_{2} \mathrm{O}$ & $\mathrm{BF}_{3} \cdot \mathrm{Et}_{2} \mathrm{O}$ & $-30{ }^{\circ} \mathrm{C}$ & $\mathbf{2 9}$ & $75 \%(1: 0)$ \\
3 & $\mathbf{2 6}$ & $\mathbf{1 8}$ & $\mathrm{Et}_{2} \mathrm{O}$ & $\mathrm{BF}_{3} \cdot \mathrm{Et}_{2} \mathrm{O}$ & $-30{ }^{\circ} \mathrm{C}$ & - & - \\
4 & $\mathbf{2 6}$ & $\mathbf{2 7}$ & $\mathrm{Et}_{2} \mathrm{O} / \mathrm{CH}_{2} \mathrm{Cl}_{2}(15: 1)$ & $\mathrm{BF}_{3} \cdot \mathrm{Et}_{2} \mathrm{O}$ & $-30{ }^{\circ} \mathrm{C}$ & $\mathbf{2 8}$ & $45 \%(1: 0)$ \\
5 & $\mathbf{2 6}$ & $\mathbf{2 7}$ & $\mathrm{Et}_{2} \mathrm{O} / \mathrm{CH}_{2} \mathrm{Cl}_{2}(8: 1)$ & $\mathrm{BF}_{3} \cdot \mathrm{Et}_{2} \mathrm{O}$ & $-30{ }^{\circ} \mathrm{C}$ & $\mathbf{2 8}$ & $50 \%(3: 1)$ \\
\hline
\end{tabular}

In this study, mannose donor without neighboring participant for glycosylation was also studied and compared in Table 2. Comparison of entry 1 and $\mathbf{2}$ indicated that using $\mathrm{Et}_{2} \mathrm{O}$ as solvent can promote $\alpha$ isomer ratio without getting $\beta$ isomer. In entry $\mathbf{3}$, when acceptor 18 was used, no desired compound was found. That is because the activity of furanose is generally higher than that in pyranose during glycosylation, leading to catalyst first activated the STol group in acceptor 18. In entry 4, with compound 27 as acceptor, pure $\alpha$ isomer 28 can be obtained in $\mathrm{Et}_{2} \mathrm{O}$ and $\mathrm{CH}_{2} \mathrm{Cl}_{2}$ mixed solution (15:1). However, when decreasing the ratio to $8: 1$ in entry $5, \beta$ isomer also appeared, which demonstrated that $\mathrm{Et}_{2} \mathrm{O}$ taking the huge part in mixed solvent that promotes a product forming.

\section{Deprotection and reduction}

Finally, in Scheme 5, with two trisaccharides (12 and 29) and three tetrasaccharides (15', 21 and 22) in hand, one step full-deprotection was performed to deprotect benzyl and acetyl groups using sodium in liquid ammonia at $-60^{\circ} \mathrm{C}$. Meanwhile, azide group was reduced during the birch reaction. The yields for the five reactions are all around $55 \%$. The five compounds will be used to conjugate TB proteins and evaluated biological activity in the future. Since it is reported that $\mathrm{SCH}_{2} \mathrm{CN}$ can also be used for protein conjugation ${ }^{[11 b]}$, we tried to deprotect the benzyl groups in compound $\mathbf{2 8}$. However, no targeting compound was detected by birch reaction, catalytic hydrogenation and other methods. For birch reaction, $\mathrm{SCH}_{2} \mathrm{CN}$ group changed to $\mathrm{SH}$ according to the mass spectrum, while catalytic hydrogenation failed to remove the benzyl group because sulfur poisoned the palladium 
promoter.
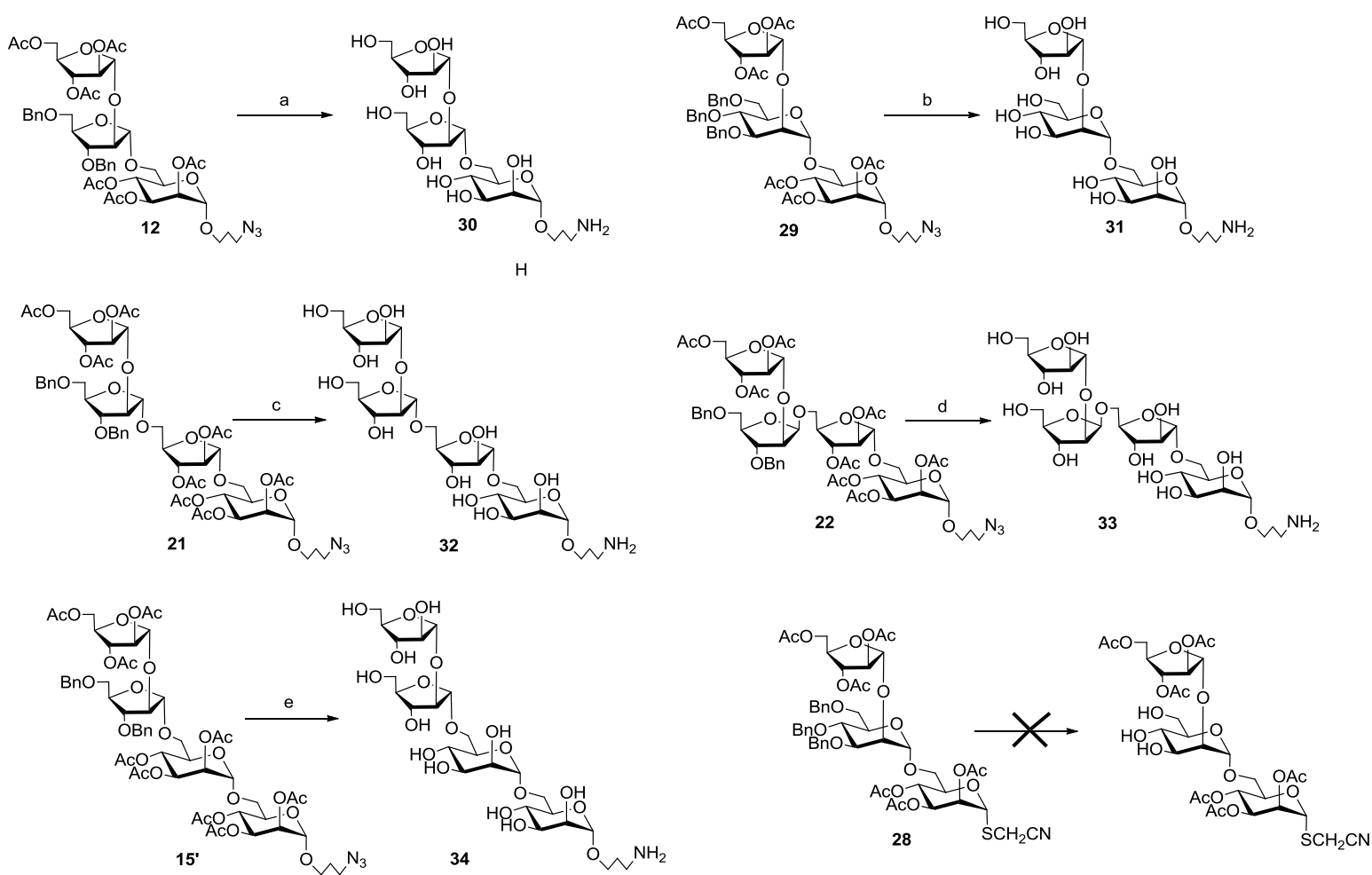

Scheme 5. Reagents and conditions: (a) to (e) liquid $\mathrm{NH}_{3}, \mathrm{Na}, \mathrm{CH}_{3} \mathrm{OH}, \mathrm{THF},-60^{\circ} \mathrm{C}, 30 \mathrm{~min}, \mathbf{3 0}(59 \%), 31$ (53\%), $32(55 \%), 33(54 \%)$ and $\mathbf{3 4}(55 \%)$, respectively.

\section{Conclusion}

In this study, a concise synthesis of five oligosaccharides derived from LAM was achieved. The key steps for highly stereoselective construction of glycosidic bonds by acceptors glycosylated with donors without neighbouring group participantion were achieved, during which the effect of $\mathrm{Et}_{2} \mathrm{O}$ was significant. Using the solvent effect of $\mathrm{Et}_{2} \mathrm{O}$ can provide products with high a selectivity for arabinose donor $\mathbf{1 1}$ and pure a products for mannose donor 25. It's noteworthy that enzymatic hydrolysis was applied to prepare mannose building blocks and one step of birch reaction was used for deprotection and reduction, which can avoid multiple chemical procedures. Finally, five oligosaccharides with amino group at reducing end were furnished which can be used for conjugation with TB protein as potential vaccines.

These are just our preliminary results. Although conjugation with proteins and 
investigations of the ability of glycoconjugates on the mycobacteria will be studied and reported in the future, it is clear that this work can accelerate the study of LAM-based vaccines and oligosaccharides related with human diseases.

\section{Experimental Section}

\section{General}

All chemicals were purchased as reagent grade and used without further purification. All reactions were carried out under Ar atmosphere and anhydrous conditions with freshly distilled solvents, unless otherwise noted. Reactions were monitored by thin-layer chromatography (TLC) on a pre-coated plate of silica gel 60 F254 (Merck) and detection by charring with sulfuric acid. Solvents were evaporated under reduced pressure and below $40{ }^{\circ} \mathrm{C}$ (water bath). Column chromatography was performed on silica gel 60 (230-400 mesh, Merck). All the new compounds were fully characterized by ${ }^{1} \mathrm{H}$ and ${ }^{13} \mathrm{C}$ NMR, as well as HRMS. ${ }^{1} \mathrm{H}$ NMR and ${ }^{13} \mathrm{C}$ NMR spectra were recorded at $400 \mathrm{MHz}$ and $100 \mathrm{MHz}$ with Bruker AVANCE DRX 400 spectrometer. The chemical shifts were referenced to the solvent peak, $7.26 \mathrm{ppm}\left({ }^{1} \mathrm{H}\right)$ and $77.16 \mathrm{ppm}\left({ }^{13} \mathrm{C}\right)$ for $\mathrm{CDCl}_{3}$ at $25{ }^{\circ} \mathrm{C}$, Chemical shifts $(\delta)$ are given in parts per million downfield from internal $\mathrm{Me}_{4} \mathrm{Si}$ or with DHO signal as a reference when $\mathrm{D}_{2} \mathrm{O}$ was used as the solvent, and coupling constants were given in Hz. Complete assignment of all NMR signals was performed using a combination of H,H-COSY and H,C-HSQC experiments. High-resolution mass spectra (HRMS) were recorded with a Bruker Micro-TOF spectrometer in electrospray ionization (ESI) mode, using Tuning-Mix as reference.

4-methylphenyl 3,5-di-O-benzyl-1-thio- $\alpha$-D-arabinofuranoside (5)

To a solution of $4(500 \mathrm{mg}, 1.04 \mathrm{mmol})$ in $\mathrm{CH}_{2} \mathrm{Cl}_{2}(5 \mathrm{~mL})$ was added $\mathrm{MeONa}$ in $\mathrm{MeOH}(1 \mathrm{M})$ until the $\mathrm{pH}$ value reached 10 . The solution was stirred at RT for $2 \mathrm{~h}$ before TLC showing the disappearance of 4. The mixture was neutralized with Amberlite IR $120\left(\mathrm{H}^{+}\right)$, filtered, and concentrated. Then the crude was purified by column chromatography to give $\mathbf{5}$ (438 $\mathrm{mg}, 96 \%$ ) as colorless syrup. $\mathrm{R}_{\mathrm{f}}=0.35$ (cyclohexane: ethyl acetate $\left.=4: 1\right) .{ }^{1} \mathrm{H}$ NMR $\left(400 \mathrm{MHz}, \mathrm{CDCl}_{3}\right) \delta 7.44$ (d, $J=7.8 \mathrm{~Hz}, 2 \mathrm{H}, \mathrm{Ph}), 7.39-7.28$ (m, 10H, Ph), 7.14 (d, $J=7.8 \mathrm{~Hz}, 2 \mathrm{H}, \mathrm{Ph}), 5.50$ (s $\left.\mathrm{s}_{\text {(br.) }}, 1 \mathrm{H}, \mathrm{H}-1\right)$, $4.76(\mathrm{~d}, J=11 \mathrm{~Hz}, 1 \mathrm{H}, \mathrm{Bn}), 4.66(\mathrm{~d}, J=11 \mathrm{~Hz}, 1 \mathrm{H}, \mathrm{Bn}), 4.51(\mathrm{~d}, J=11 \mathrm{~Hz}, 1 \mathrm{H}, \mathrm{Bn}), 4.50$ (dd, $J_{3,4}$ $\left.=1.7 \mathrm{~Hz}, J_{4,5}=2.5 \mathrm{~Hz}, 1 \mathrm{H}, \mathrm{H}-4\right), 4.47(\mathrm{~d}, J=11 \mathrm{~Hz}, 1 \mathrm{H}, \mathrm{Bn}), 4.37\left(\mathrm{dt}, J_{1,2}<1 \mathrm{~Hz}, J_{2,3}=1.1 \mathrm{~Hz}\right.$, $\left.J_{2, \mathrm{OH}}=10.3 \mathrm{~Hz}, \mathrm{H}-2\right), 3.99\left(\mathrm{dd}, J_{2,3}=1.1 \mathrm{~Hz}, J_{3,4}=1.7 \mathrm{~Hz}, 1 \mathrm{H}, \mathrm{H}-3\right), 3.77(\mathrm{~d}, J=10.3 \mathrm{~Hz}, 1 \mathrm{H}$, $\mathrm{OH}), 3.74(\mathrm{~m}, 1 \mathrm{H}, \mathrm{H}-5), 3.59$ (dd, $\left.J_{4,5}=2.5 \mathrm{~Hz}, J_{5,5^{\prime}}=10.5 \mathrm{~Hz}, 1 \mathrm{H}, \mathrm{H}-5^{\prime}\right), 2.35$ (s, 3H, Tol). ${ }^{13} \mathrm{C}$ NMR $\left(100 \mathrm{MHz}, \mathrm{CDCl}_{3}\right) \delta 137.56,137.16,136.92,131.91,129.70,128.59,128.49,128.12$, 127.89, 127.86, 127.82, 95.43 (C-1), 85.15, 83.42, 79.03, 73.82, 72.10, 69.63, 21.09.HR ESI-TOF MS (m/z): calcd for $\mathrm{C}_{26} \mathrm{H}_{28} \mathrm{O}_{4} \mathrm{SNa}[\mathrm{M}+\mathrm{Na}]^{+}, 459.1601$; found, 459.1605 .

4-methylphenyl

(2,3,5-tri-O-acetyl- $\alpha$-D-arabinofuranosyl)-3,5-di-O-benzyl-1-thio- $\alpha$-D-arabinofuranoside (6)

The dried 5 (438 mg, $1.01 \mathrm{mmol}), \mathbf{3}(635 \mathrm{mg}, 1.15 \mathrm{mmol})$ and activated $4 \AA$ MS $(1 \mathrm{~g})$ were mixed together in anhydrous DCM $(4 \mathrm{~mL})$. The mixture was stirred for $1 \mathrm{~h}$ at $\mathrm{RT}$ under argon. $\mathrm{BF}_{3} \cdot \mathrm{Et}_{2} \mathrm{O}$ 
( $35 \mu \mathrm{L}, 0.23 \mathrm{mmol}$ ) was added and the reaction was left for $20 \mathrm{~min}$ at $-50{ }^{\circ} \mathrm{C}$. The mixture was stirred at RT for $1 \mathrm{~h}$ before adding triethylamine. After concentration the resulting crude product was purified by column chromatography (cyclohexane: ethyl acetate $=4: 1$ ) getting compound 6 $(600 \mathrm{mg}, 85 \%)$ as colorless syrup. $\mathrm{R}_{\mathrm{f}}=0.4$ (cyclohexane: ethyl acetate $\left.=2: 1\right) .{ }^{1} \mathrm{H}-\mathrm{NMR}(400 \mathrm{~Hz}$, $\left.\mathrm{CDCl}_{3}\right) \delta$ 7.46-7.28 (m, 12H, Ph), 7.14-7.07 (d, $\left.J=9.58 \mathrm{~Hz}, 2 \mathrm{H}, \mathrm{Ph}\right), 5.44(\mathrm{~d}, J=3.25 \mathrm{~Hz}, 1 \mathrm{H}$, $\left.\mathrm{H}-1^{\text {Ara-A }}\right), 5.11\left(\mathrm{~s}, 1 \mathrm{H}, \mathrm{H}-1^{\text {Ara-B }}\right), 5.04\left(\mathrm{~d}, J=1.60 \mathrm{~Hz}, 1 \mathrm{H}, \mathrm{H}-2^{\text {Ara-B }}\right), 4.97\left(\mathrm{dd}, J_{2,3}=1.60 \mathrm{~Hz}, J_{3,4}\right.$ $\left.=5.14 \mathrm{~Hz}, 1 \mathrm{H}, \mathrm{H}-3^{\text {Ara-B }}\right), 4.20\left(\mathrm{~m}, 1 \mathrm{H}, \mathrm{H}-4^{\text {Ara-B }}\right), 4.43-4.35\left(\mathrm{~m}, 1 \mathrm{H}, \mathrm{H}-5^{\text {Ara-B }}\right), 4.30(\mathrm{~m}, 1 \mathrm{H}$, $\left.\mathrm{H}-4^{\text {Ara-A }}\right), 4.27\left(\mathrm{~m}, 1 \mathrm{H}, \mathrm{H}-2^{\text {Ara-A }}\right), 4.26-4.19\left(\mathrm{~m}, 1 \mathrm{H}, \mathrm{H}-5^{\text {'Ara-B }}\right), 4.04\left(\mathrm{~m}, 1 \mathrm{H}, \mathrm{H}-3^{\text {Ara-A }}\right), 3.61(\mathrm{~m}, 2 \mathrm{H}$, H- ${ }^{\text {Ara-A }}$ ), 2.27 (s, 3H, Tol), 2.06 (s, 3H, Ac), 2.00 (s, 3H, Ac), 1.99 (s, 3H, Ac). ${ }^{13} \mathrm{C}$ NMR $(400 \mathrm{~Hz}$, $\left.\mathrm{CHCl}_{3}\right) \delta 138.02,137.65,137.56,132.44,130.65,129.67,128.38,127.83,127.73,127.66,106.61$ $\left(\mathrm{C}-1^{\text {Ara-B }}\right), 91.10\left(\mathrm{C}-1^{\text {Ara-A }}\right), 86.65,83.11,81.62,80.63,80.21,73.34,72.43,68.99,63.24,26.93$, 21.11, 20.75, 20.70. HR ESI-TOF MS $(\mathrm{m} / \mathrm{z})$ : calcd for $\mathrm{C}_{37} \mathrm{H}_{42} \mathrm{O}_{11} \mathrm{~S}[\mathrm{M}+\mathrm{Na}]^{+}, 717.2340$; found 717.2340

\section{3-Azidopropyl 2,3,4-tri-O-acetyl- $\alpha$-D-mannopyranoside (9)}

The enzymatic hydrolysis of compound $\mathbf{8}(0.45 \mathrm{~g}, 1.04 \mathrm{mmol})$ was carried out in $50 \mathrm{mM} \mathrm{KH} \mathrm{KO}_{4}$ buffer $\mathrm{pH} 4$ containing $30 \%$ acetonitrile for complete solubilisation of the substrate $(104 \mathrm{~mL})$ under magnetic stirring. The reactions started after addition of the immobilized CRL (3 g, 1400 $\mathrm{IU} / \mathrm{g}$ ). During the reaction $\mathrm{pH}$ value was maintained constant. The course of the hydrolysis was monitored by TLC. After $24 \mathrm{~h}$ the reaction was stopped by biocatalyst filtration and the reaction mixture was extracted with ethyl acetate. After evaporation of the solvent under reduced pressure the residue was purified by flash chromatography to obtain the product $9(0.347 \mathrm{~g}, 85 \%)$. $\mathbf{R}_{\mathrm{f}}=$ 0.25 (cyclohexane: ethyl acetate $=4: 1) .{ }^{1} \mathrm{H} \mathrm{NMR}\left(400 \mathrm{MHz}, \mathrm{CDCl}_{3}\right) \delta 5.37\left(\mathrm{dd}, J_{2,3}=3.5 \mathrm{H}_{\mathrm{Z}}, J_{3,4}\right.$ $=8.6 \mathrm{~Hz}, 1 \mathrm{H}, \mathrm{H}-3), 5.26-5.20(\mathrm{~m}, 2 \mathrm{H}, \mathrm{H}-2, \mathrm{H}-4), 4.82(\mathrm{~d}, J=1.6 \mathrm{~Hz}, 1 \mathrm{H}, \mathrm{H}-1), 3.84-3.65(\mathrm{~m}, 2 \mathrm{H}$, H-5, H-6), 3.66-3.47 (m, 2H, $\mathrm{CH}_{2}$ ), 3.42 (t, $\left.J=6.19 \mathrm{~Hz}, 2 \mathrm{H}, \mathrm{CH}_{2}\right), 2.38-2.34(\mathrm{~m}, 1 \mathrm{H}, \mathrm{OH}), 2.14$ (s, $3 \mathrm{H}, \mathrm{Ac}$ ); 2.07 (s, 3H, Ac), 2.00 (s, 3H, Ac), 1.92-1.83 (m, 2H, $\left.\mathrm{CH}_{2}\right) .{ }^{13} \mathrm{C} \mathrm{NMR} \mathrm{(100} \mathrm{MHz,} \mathrm{CDCl}_{3}$ ) $\delta 170.79,170.08,169.88,97.69$ (C-1), 70.80, 69.56, 68.83, 66.41, 64.78, 61.26, 48.13, 28.68, 20.87, 20.74, 20.70. HR ESI-TOF MS $(\mathrm{m} / z)$ : calcd for $\mathrm{C}_{30} \mathrm{H}_{46} \mathrm{~N}_{6} \mathrm{O}_{18} \mathrm{Na}[2 \mathrm{M}+\mathrm{Na}]^{+}, 801.2761$; found 801.2748

3-Azidopropyl

(2,3,4-tri-O-acetyl- $\alpha$-D-arabinofuranosyl)-( $(1 \rightarrow 2)-(3,5-d i-O-b e n z y l-\alpha$-D-arabino-furanosyl)-( $1 \rightarrow 6)$ 2,3,4-tri-O-acetyl- $\alpha$-D-mannopyranoside (12)

To a solution of 6 (600 mg, $0.86 \mathrm{mmol})$ in $16 \mathrm{~mL}$ wet $\mathrm{CH}_{2} \mathrm{Cl}_{2}\left(20 \% \mathrm{H}_{2} \mathrm{O}\right)$ was added NIS (390 mg, $1.72 \mathrm{mmol}), \operatorname{AgOTf}(221 \mathrm{mg}, 0.86 \mathrm{mmol})$ and TTBP $(640 \mathrm{mg}, 2.58 \mathrm{mmol})$. The solution was stirred for $1 \mathrm{~h}$ until no $\mathbf{6}$ left. The crude was purified by column chromatography to give $\mathbf{1 0}$ (462 $\mathrm{mg}, 91 \%$ ) as colorless syrup. $\mathrm{R}_{\mathrm{f}}=0.5$ (cyclohexane: ethyl acetate $=1: 1$ ). All the $\mathbf{1 0}$ was immediately put into $6 \mathrm{~mL}$ dry DCM under argon and then $\mathrm{CCl}_{3} \mathrm{CN}(780 \mu \mathrm{L}, 8.6 \mathrm{mmol})$ and DBU $(130 \mu \mathrm{L}, 0.86 \mathrm{mmol})$ were added to the solution at ice bath. The solution was stirred for $1 \mathrm{~h}$ at $0{ }^{\circ} \mathrm{C}$ and solution was removed under vacuo and purified by column chromatography with $1 \%$ triethylamine added cyclohexane/ethyl acetate $(3 / 2) . R_{f}=0.5$ (cyclohexane: ethyl acetate $=3: 2$ ). 11 should be used without delay for its poor stability. The dried 11 (50 mg, $0.068 \mathrm{mmol}), \mathbf{9}$ (43 $\mathrm{mg}, 0.11 \mathrm{mmol})$ and activated $4 \AA \mathrm{MS}(100 \mathrm{mg})$ were mixed together in anhydrous $\mathrm{Et}_{2} \mathrm{O}(1.5 \mathrm{~mL})$. 
The mixture was stirred for $1 \mathrm{~h}$ at $\mathrm{RT}$ under argon. $\mathrm{BF}_{3} \cdot \mathrm{Et}_{2} \mathrm{O}(10 \mu \mathrm{L}, 0.07 \mathrm{mmol})$ was added and the reaction was left for $1 \mathrm{~h}$ at $-30{ }^{\circ} \mathrm{C}$ before being quenched by triethylamine. The resulting crude product was purified by column chromatography (DCM: ethyl acetate $=8: 1)$ getting $12(45 \mathrm{mg}$, 69\%)as colorless syrup. $\mathrm{R}_{\mathrm{f}}=0.3$ (DCM: ethyl acetate $\left.=8: 1\right) .{ }^{1} \mathrm{H}$ NMR $\left(400 \mathrm{MHz}, \mathrm{CDCl}_{3}\right) \delta$ 7.27-7.18 (m, 10H, Ph), 5.26-5.11 (m, 3H), 4.99-4.97 (m, 2H, H-1 $\left.{ }^{\text {Ara-A }}, \mathrm{H}-1^{\text {Ara-B }}\right), 4.70(\mathrm{~s}, 1 \mathrm{H}$, $\left.\mathrm{H}-1^{\mathrm{Man}}\right), 4.97-4.96(\mathrm{~m}, 1 \mathrm{H}), 4.94-4.92(\mathrm{~m}, 1 \mathrm{H}), 4.52(\mathrm{~d}, J=11.8 \mathrm{~Hz}, 2 \mathrm{H}, \mathrm{Bn}), 4.47$ (d, $J=11.8 \mathrm{~Hz}$, $1 \mathrm{H}, \mathrm{Bn}), 4.45(\mathrm{~d}, J=11.8 \mathrm{~Hz}, 1 \mathrm{H}, \mathrm{Bn}), 4.33-4.28(\mathrm{~m}, 1 \mathrm{H}), 4.21-4.11(\mathrm{~m}, 4 \mathrm{H}), 3.87-3.67(\mathrm{~m}, 4 \mathrm{H})$, 3.59-3,52 (m, 2H), 3.51-3.34 (m, 2H, CH$), 3.28\left(\mathrm{t}, J=6.7 \mathrm{~Hz}, 2 \mathrm{H}, \mathrm{CH}_{2}\right), 2.03(\mathrm{~s}, 3 \mathrm{H}, \mathrm{Ac}), 2.02(\mathrm{~s}$, 3H, Ac), 1.99 (s, 3H, Ac), 1.98 (s, 3H, Ac), 1.94 (s, 3H, Ac), 1.92 (s, 3H, Ac), 1.75-1.70 (m, 2H, $\left.\mathrm{CH}_{2}\right) .{ }^{13} \mathrm{C}$ NMR $\left(100 \mathrm{MHz}, \mathrm{CDCl}_{3}\right) \delta 170.45,170.14,170.03,169.95,169.70,169.57,138.06$, $137.84,128.33,128.31,127.75,127.73,127.69,127.63,106.46\left(\mathrm{C}-1^{\text {Ara-A }}\right), 105.31\left(\mathrm{C}-1^{\text {Ara-B }}\right)$, $97.41\left(\mathrm{C}-1^{\mathrm{Man}}\right), 86.52,83.43,81.76,80.77,80.41,76.86,73.34,72.13,69.64,69.59,69.42,69.33$, $66.99,66.18,64.73,63.06,48.19,28.60,20.80,20.76,20.73,20.71,20.69$. HR ESI-TOF MS $(\mathrm{m} / \mathrm{z})$ : calcd for $\mathrm{C}_{45} \mathrm{H}_{57} \mathrm{~N}_{3} \mathrm{O}_{20} \mathrm{NH}_{4}\left[\mathrm{M}+\mathrm{NH}_{4}\right]^{+}$, 977.3880; found, 977.3874 .

4-methylphenyl

$(2,3,4-$ tri-O-acetyl- $\alpha$-D-arabinofuranosyl)-( $(1 \rightarrow 2)-(3,5-d i-O-b e n z y l-\alpha-D-a r a b i n o-f u r a n o s y l)-(1 \rightarrow 6)-$ 2,3,4-tri-O-acetyl-1-thio- $\alpha$-D-mannopyranoside (15)

The dried $\mathbf{1 1}(50 \mathrm{mg}, 0.068 \mathrm{mmol}), \mathbf{1 3}$ (45 mg, $0.11 \mathrm{mmol})$ and activated $4 \AA \mathrm{MS}$ (100 mg) were mixed together in anhydrous $\mathrm{Et}_{2} \mathrm{O}(1.5 \mathrm{~mL})$ stirred for $1 \mathrm{~h}$ at $\mathrm{RT}$ under argon. Then $\mathrm{BF}_{3} \cdot \mathrm{Et}_{2} \mathrm{O}(10$ $\mu \mathrm{L}, 0.07 \mathrm{mmol}$ ) was added and the reaction was left for $1 \mathrm{~h}$ at $-30{ }^{\circ} \mathrm{C}$ before quenching by triethylamine. After filtering by Celite and concentration, the resulting crude product was purified by column chromatography (DCM: ethyl acetate $=8: 1)$ getting $15(36 \mathrm{mg}, 60 \%)$ as colorless syrup. $\mathrm{R}_{\mathrm{f}}=0.5$ (cyclohexane: ethyl acetate $\left.=3: 2\right) .{ }^{1} \mathrm{H} \mathrm{NMR}\left(400 \mathrm{MHz}, \mathrm{CDCl}_{3}\right) \delta 7.32(\mathrm{~d}, J=8.4$ $\mathrm{Hz}, 2 \mathrm{H}, \mathrm{Ph}), 7.26-7.19(\mathrm{~m}, 10 \mathrm{H}, \mathrm{Ph}), 7.02(\mathrm{~d}, J=8.4 \mathrm{~Hz}, 2 \mathrm{H}, \mathrm{Ph}), 5.38(\mathrm{~m}, 1 \mathrm{H}), 5.30$ (d, $J=1.43$ $\left.\mathrm{Hz}, 1 \mathrm{H}, \mathrm{H}-1^{\mathrm{Man}}\right), 5.27-5.21(\mathrm{~m}, 2 \mathrm{H}), 4.98\left(\mathrm{~s}, 1 \mathrm{H}, \mathrm{H}-1^{\text {Ara-A }}\right), 4.97\left(\mathrm{~s}, 1 \mathrm{H}, \mathrm{H}-1^{\text {Ara-B }}\right), 4.96-4.92(\mathrm{~m}$, $2 \mathrm{H}), 4.55(\mathrm{~d}, J=11.8 \mathrm{~Hz}, \mathrm{Bn}), 4.53-4.46(\mathrm{~m}, 3 \mathrm{H}, \mathrm{Bn}), 4.45-4.44(\mathrm{~m}, 1 \mathrm{H}), 4.27\left(\mathrm{dd}, J_{1}=3.2 \mathrm{~Hz}, J_{2}\right.$ $=11.1 \mathrm{~Hz}, 1 \mathrm{H}), 4.17-4.11(\mathrm{~m}, 4 \mathrm{H}), 3.86-3.81(\mathrm{~m}, 2 \mathrm{H}), 3.59-3.48(\mathrm{~m}, 3 \mathrm{H}) ; 2.18\left(\mathrm{~s}, 3 \mathrm{H}, \mathrm{CH}_{3}\right), 2.02$ (s, 3H, $\left.\mathrm{CH}_{3}\right), 1.98$ (s, 3H, CH $), 1.97$ (s, 3H, $\left.\mathrm{CH}_{3}\right), 1.96$ (s, 3H, $\left.\mathrm{CH}_{3}\right), 1.94\left(\mathrm{~s}, 3 \mathrm{H}, \mathrm{CH}_{3}\right) .{ }^{13} \mathrm{C} \mathrm{NMR}$ $\left(100 \mathrm{MHz}, \mathrm{CDCl}_{3}\right) \delta 170.46,170.05,170.03,169.89,169.72,169.58,138.27,138.05,137.88$, $132.71,129.92,129.29,128.33,128.31,127.76,127.74,127.66,127.62,106.51\left(\mathrm{C}-1^{\text {Ara-A }}\right), 105.37$ $\left(\mathrm{C}-1^{\text {Ara-B }}\right), 86.93\left(\mathrm{C}-1^{\mathrm{Man}}\right), 86.29,83.25,81.78,80.45,80.42,73.34,72.15,71.12,70.28,69.68$, $69.37,67.20,66.30,63.06,21.05,20.80,20.78,20.72,20.69$. HR ESI-TOF MS $(\mathrm{m} / \mathrm{z})$ : calcd for $\mathrm{C}_{49} \mathrm{H}_{58} \mathrm{O}_{19} \mathrm{SNH}_{4}\left[\mathrm{M}+\mathrm{NH}_{4}\right]^{+}$, 1000.3631; found, 1000.3636.

\section{3-Azidopropyl}

$(2,3,4-$ tri-O-acetyl- $\alpha$-D-arabinofuranosyl)-( $1 \rightarrow 2)$-(3,5-di-O-benzyl- $\alpha$-D-arabino-furanosyl)-( $1 \rightarrow 6)$ (2,3,4-tri-O-acetyl- $\alpha$-D-mannopyranosyl)-( $(1 \rightarrow 6)-2,3,4$-tri-O-acetyl- $\alpha$-D-mannopyranoside (15')

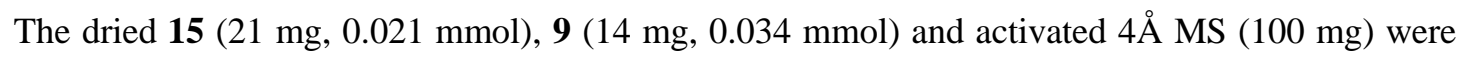
mixed together in anhydrous DCM $(1.5 \mathrm{~mL})$ stirred for $1 \mathrm{~h}$ at RT under argon. Then NIS (14 mg, $0.063 \mathrm{mmol})$ and TMSOTf $(6 \mu \mathrm{L}, 0.03 \mathrm{mmol})$ were added and the reaction was left for $1 \mathrm{~h}$ at $-10{ }^{\circ} \mathrm{C}$ before filtering by Celite, then the solution was washed with saturated aq. $\mathrm{Na}_{2} \mathrm{~S}_{2} \mathrm{O}_{3}$, $\mathrm{NaHCO}_{3}$, water and dried over $\mathrm{MgSO}_{4}$. After concentration, the resulting crude product was purified by column chromatography (cyclohexane: ethyl acetate $=1: 1)$ getting $\mathbf{1 5}^{\prime}(20 \mathrm{mg}, 78 \%)$ as colorless syrup. $\mathrm{R}_{\mathrm{f}}=0.5$ (cyclohexane: ethyl acetate $\left.=1: 2\right) .{ }^{1} \mathrm{H} \mathrm{NMR}\left(400 \mathrm{MHz}, \mathrm{CDCl}_{3}\right) \delta$ 
7.34-7.23 (m, 10H, Ph), 5.33-5.29 (m, 3H), 5.26-5.22 (m, 3H), 5.07 (s, $\left.1 \mathrm{H}, \mathrm{H}-1^{\text {Ara-B }}\right), 5.05(\mathrm{~s}, 1 \mathrm{H}$, $\left.\mathrm{H}-1^{\text {Ara-A }}\right), 5.04(\mathrm{~d}, J=1.7 \mathrm{~Hz}, 1 \mathrm{H}), 5.00\left(\mathrm{dd}, J_{1}=1.3 \mathrm{~Hz}, J_{2}=4.9 \mathrm{~Hz}, 1 \mathrm{H}\right), 4.85\left(\mathrm{~s}, 1 \mathrm{H}, \mathrm{H}-1^{\text {Man-A }}\right)$, $4.77\left(\mathrm{~s}, 1 \mathrm{H}, \mathrm{H}-1^{\text {Man-B }}\right), 4.61(\mathrm{~d}, J=11.8 \mathrm{~Hz}, 1 \mathrm{H}, \mathrm{Bn}), 4.58(\mathrm{~d}, J=11.8 \mathrm{~Hz}, 1 \mathrm{H}, \mathrm{Bn}), 4.55$ (d, $J=$ $11.8 \mathrm{~Hz}, 1 \mathrm{H}, \mathrm{Bn}), 4.53(\mathrm{~d}, J=11.8 \mathrm{~Hz}, 1 \mathrm{H}, \mathrm{Bn}), 4.38(\mathrm{~d}, J=9.5 \mathrm{~Hz}, 1 \mathrm{H}), 4.27-4.19$ (m, 4H), 3.99 (m, 1H), 3.90-3.79 (m, 5H), 3.66-3.49 (m, 5H), $3.42(\mathrm{t}, J=6.3 \mathrm{~Hz}, 2 \mathrm{H}), 2.14$ (s, 3H, Ac), 2.10 (s, 3H, Ac), 2.10 (s, 3H, Ac), 2.06 (s, 3H, Ac), 2.04 (s, 3H, Ac), 2.04 (s, 3H, Ac), 2.00 (s, 3H, Ac), 1.99(s, 3H, Ac), 1.98(s, 3H, Ac), 1.91-1.88 (m, 2H). ${ }^{13} \mathrm{C}$ NMR (100 MHz, $\left.\mathrm{CDCl}_{3}\right) \delta 170.49$, $170.19,170.11,170.06,169.89,169.80,169.74,169.63,169.57,138.05,137.85,128.33,128.31$, 127.78, 127.74, $106.49\left(\mathrm{C}-1^{\text {Ara-B }}\right), 105.27\left(\mathrm{C}-1^{\text {Ara-A }}\right), 97.40\left(\mathrm{C}-1^{\text {Man-A }}, \mathrm{C}-1^{\text {Man-B }}\right), 86.46,83.31$, $81.77,80.78,80.41,77.22,76.89,73.36,72.07,69.56,69.51,69.32,69.23,69.20,66.83,66.49$, 66.39, 65.98, 64.92, 63.13, 48.20, 28.67, 20.80, 20.78, 20.75, 20.70.HR ESI-TOF MS ( $\mathrm{m} / \mathrm{z})$ : calcd for $\mathrm{C}_{57} \mathrm{H}_{73} \mathrm{~N}_{3} \mathrm{O}_{28} \mathrm{Na}[\mathrm{M}+\mathrm{Na}]^{+}$, 1270.4273; found, 1279.4230 .

2,3,4-tri-O-acetyl- $\alpha$-D-arabinofuranosyl-( $1 \rightarrow 2)$-3,5-di-O-benzyl- $\alpha$-D-arabino-furanosyl-( $(1 \rightarrow 6)-1,2$, 3,4-tetra-O-acetyl- $\alpha$-D-mannopyranoside (16)

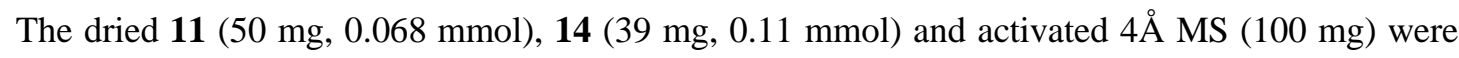
mixed together in anhydrous $\mathrm{Et}_{2} \mathrm{O}(1.5 \mathrm{~mL})$. The mixture was stirred for $1 \mathrm{~h}$ at $\mathrm{RT}$ under argon. $\mathrm{BF}_{3} \cdot \mathrm{Et}_{2} \mathrm{O}(10 \mu \mathrm{L}, 0.07 \mathrm{mmol})$ was added and the reaction was left for $20 \mathrm{~min}$ at $-30{ }^{\circ} \mathrm{C}$ before quenching by triethylamine. After filtering by Celite and concentration, the resulting crude product was purified by column chromatography (DCM: ethyl acetate $=8: 1)$ getting $16(41 \mathrm{mg}$, $65 \%)$ as colorless syrup. $\mathrm{R}_{\mathrm{f}}=0.45$ (cyclohexane: ethyl acetate $\left.=1: 1\right) .{ }^{1} \mathrm{H} \mathrm{NMR}\left(400 \mathrm{MHz}, \mathrm{CDCl}_{3}\right)$ $\delta$ 7.33-7.24 (m, 10H), $6.06\left(\mathrm{~d}, J=1.9 \mathrm{~Hz}, 1 \mathrm{H}, \mathrm{H}-1^{\mathrm{Man}}\right), 5.38-5.34(\mathrm{~m}, 4 \mathrm{H}), 5.22(\mathrm{~m}, 1 \mathrm{H}), 5.03$ $(\mathrm{m}, 1 \mathrm{H}), 5.04\left(\mathrm{~s}, 1 \mathrm{H}, \mathrm{H}-1^{\text {Ara-B }}\right), 5.02\left(\mathrm{~s}, 1 \mathrm{H}, \mathrm{H}-1^{\text {Ara-A }}\right), 5.00(\mathrm{~m}, 1 \mathrm{H}), 4.61(\mathrm{~d}, J=11.8 \mathrm{~Hz}, 1 \mathrm{H}, \mathrm{Bn})$, $4.58(\mathrm{~d}, J=11.8 \mathrm{~Hz}, 1 \mathrm{H}, \mathrm{Bn}), 4.55-4.51(\mathrm{~m}, 2 \mathrm{H}, \mathrm{Bn}), 4.38(\mathrm{~d}, J=8.4 \mathrm{~Hz}, 1 \mathrm{H}), 4.26-4.19$ (m, 4H), $4.01(\mathrm{~m}, 1 \mathrm{H}), 3.89\left(\mathrm{dd}, J_{1}=2.5 \mathrm{~Hz}, J_{2}=6.4 \mathrm{~Hz}, 1 \mathrm{H}\right), 3.84\left(\mathrm{dd}, J_{1}=4.3 \mathrm{~Hz}, J_{2}=11 \mathrm{~Hz}, 1 \mathrm{H}\right)$, 3.65-3.56 (m, 3H), 2.12 (s, 3H, $\mathrm{CH}_{3}$ ), 2.10 (s, 3H, $\mathrm{CH}_{3}$ ), 2.09 (s, 3H, $\left.\mathrm{CH}_{3}\right), 2.08\left(\mathrm{~s}, 3 \mathrm{H}, \mathrm{CH}_{3}\right), 2.05$ (s, 3H, $\left.\mathrm{CH}_{3}\right), 2.01\left(\mathrm{~s}, 3 \mathrm{H}, \mathrm{CH}_{3}\right), 2.00\left(\mathrm{~s}, 3 \mathrm{H}, \mathrm{CH}_{3}\right) .{ }^{13} \mathrm{C}$ NMR $\left(100 \mathrm{MHz}, \mathrm{CDCl}_{3}\right) \delta 170.49,170.05$, $169.85,169.57,169.48,168.15,138.05,137.84,128.33,128.31,127.76,127.74,127.67,127.63$, $106.60\left(\mathrm{C}-1^{\text {Ara-B }}\right), 105.31\left(\mathrm{C}-1^{\text {Ara-A }}\right), 90.56\left(\mathrm{C}-1^{\mathrm{Man}}\right), 86.53,83.25,81.75,80.61,80.41,76.84$, $73.33,72.10,71.23,69.50,68.99,68.43,66.63,66.27,63.04,20.83,20.72,20.70,20.68$. HR ESI-TOF MS ( $/ \mathrm{z} / z)$ : calcd for $\mathrm{C}_{44} \mathrm{H}_{54} \mathrm{O}_{21} \mathrm{NH}_{4}\left[\mathrm{M}+\mathrm{NH}_{4}\right]^{+}$, 936.3499 ; found, 936.3496 .

4-methylphenyl 2,3-di-O-acetyl-1-thio- $\alpha$-D-arabinofuranoside (18)

Compound 17 (280 mg, $0.72 \mathrm{mmol})$ was dissolved in DCM $(6 \mathrm{~mL})$ with p-thiocresol (142 $\mathrm{mg}$, $0.86 \mathrm{mmol})$. Then $\mathrm{BF}_{3} \cdot \mathrm{Et}_{2} \mathrm{O}(230 \mu \mathrm{L}, 1.28 \mathrm{mmol})$ was added to the solution at $0{ }^{\circ} \mathrm{C}$ and the mixture was stirred for $1 \mathrm{~h}$ before being quenched by triethylamine and evporation. The resulting product was purified by column chromatography (cyclohexane: ethyl acetate $=3: 2$ ). Compound 18 was gotten $(160 \mathrm{mg}, 66 \%)$ as white foam. $R_{\mathrm{f}}=0.35$ (cyclohexane: ethyl acetate $=3: 2$ ). ${ }^{1} \mathrm{H}$ NMR (400 MHz, $\left.\mathrm{CDCl}_{3}\right) \delta 5.47(\mathrm{~d}, J=2.5 \mathrm{~Hz}, 1 \mathrm{H}, \mathrm{H}-1), 5.30(\mathrm{t}, J=2.5 \mathrm{~Hz}, 1 \mathrm{H}, \mathrm{H}-2), 5.12(\mathrm{~m}$, 1H, H-3), 4.35 (m, 1H, H-4), 3.93-3.79 (m, 2H, H-5, H-5'), 2.34 (s, 3H, Tol), 2.14 (s, 3H, Ac), 2.09 (s, 3H, Ac), 2.02-1.99 (m, 1H, OH). ${ }^{13} \mathrm{C}$ NMR (100 MHz, $\left.\mathrm{CDCl}_{3}\right) \delta 170.46,169.67,138.16$, 132.83, 129.85, 129.58, 91.10 (C-1), 82.59, 81.71, 77.08, 61.57, 21.14, 20.81, 20.76. HR ESI-TOF MS (m/z): calcd for $\mathrm{C}_{16} \mathrm{H}_{20} \mathrm{O}_{6} \mathrm{SNa}[\mathrm{M}+\mathrm{Na}]^{+}$, 363.0873; found, 363.0880 . 
4-methylphenyl

(2,3,5-tri-O-acetyl- $\alpha$-D-arabinofuranosyl)-( $1 \rightarrow 2)$-(3,5-di-O-benzyl- $\alpha$-D-arabinofuranosyl)-( $(1 \rightarrow 5)-2$ ,3-di-O-acetyl-1-thio- $\alpha$-D-arabinofuranoside (19)

The dried 11 (270 mg, $0.37 \mathrm{mmol}), \mathbf{1 8}$ (189 mg, $0.56 \mathrm{mmol})$ and activated $4 \AA$ MS (500 mg) were mixed together in anhydrous $\mathrm{Et}_{2} \mathrm{O}(6 \mathrm{~mL})$. The mixture was stirred for $1 \mathrm{~h}$ at $\mathrm{RT} \mathrm{BF}_{3} \cdot \mathrm{Et}_{2} \mathrm{O}(13 \mu \mathrm{L}$, $0.1 \mathrm{mmol}$ ) was added and the reaction was left for $1 \mathrm{~h}$ at $-30{ }^{\circ} \mathrm{C}$ before adding triethylamine and being filtered through Celite. After concentration the resulting crude product was purified by column chromatography twice (cyclohexane: ethyl acetate $=1: 1$ and DCM: ethyl acetate $=10: 1$ ). $19(197 \mathrm{mg}, 58 \%)$ was gotten as white foam. $\mathrm{R}_{\mathrm{f}}=0.5$ (cyclohexane: ethyl acetate $\left.=1: 1\right) .{ }^{1} \mathrm{H}$ NMR $\left(400 \mathrm{MHz}, \mathrm{CDCl}_{3}\right) \delta$ 7.42-7.37 (d, $\left.J=7.9 \mathrm{~Hz}, 2 \mathrm{H}, \mathrm{Ph}\right), 7.35-7.27$ (m, 10H, Ph), 7.12-7.07 (d, $J=$ $7.9 \mathrm{~Hz}, 2 \mathrm{H}, \mathrm{Ph}), 5.44\left(\mathrm{~d}, J=1.4 \mathrm{~Hz}, 1 \mathrm{H}, \mathrm{H}-1^{\text {Ara-A }}\right), 5.22-5.20(\mathrm{~m}, 2 \mathrm{H}), 5.10\left(\mathrm{~s}, 1 \mathrm{H}, \mathrm{H}-1^{\text {Ara-C }}\right), 5.04$ $\left(\mathrm{s}, 1 \mathrm{H}, \mathrm{H}-1^{\text {Ara-B }}\right), 5.03(\mathrm{~m}, 1 \mathrm{H}), 4.99(\mathrm{~m}, 1 \mathrm{H}), 4.60-4.50(\mathrm{~m}, 4 \mathrm{H}, \mathrm{Bn}), 4.44-4.19(\mathrm{~m}, 6 \mathrm{H})$, 4.01-3.96 (dd, $\left.J_{1}=4.3 \mathrm{~Hz}, J_{2}=11.1 \mathrm{~Hz}, 1 \mathrm{H}\right), 3.92-3.89\left(\mathrm{dd}, J_{1}=2.6 \mathrm{~Hz}, J_{2}=6.1 \mathrm{~Hz}, 1 \mathrm{H}\right)$, 3.75-3.70 (dd, $\left.J_{1}=3.7 \mathrm{~Hz}, J_{2}=11.2 \mathrm{~Hz}, 1 \mathrm{H}\right), 3.66-3.57(\mathrm{~m}, 2 \mathrm{H}), 2.31(\mathrm{~s}, 3 \mathrm{H}, \mathrm{Tol}), 2.10(\mathrm{~s}, 3 \mathrm{H}$, Ac), 2.07 (s, 3H, Ac), 2.07 (s, 3H, Ac), 2.04 (s, 3H, Ac), 2.01 (s, 3H, Ac). ${ }^{13} \mathrm{C}$ NMR (100 MHz, $\left.\mathrm{CDCl}_{3}\right) \delta 170.47,170.06,169.91,169.76,169.57,139.08,138.88,138.78,132.72,129.74$, $128.33,127.70,127.75,127.74,127.69,127.61 ; 106.55\left(\mathrm{C}-1^{\text {Ara-C }}\right), 106.38\left(\mathrm{C}-1^{\text {Ara-B }}\right), 90.84$ $\left(\mathrm{C}-1^{\text {Ara-A }}\right), 86.72,83.16,81.69,80.78,80.46,77.22,76.86,73.32,72.09,69.49,65.91,63.13,21.1$, 20.77, 20.73, 20.72, 20.69, 20.68. HR ESI-TOF MS (m/z): calcd for $\mathrm{C}_{46} \mathrm{H}_{54} \mathrm{O}_{17} \mathrm{SNa}[\mathrm{M}+\mathrm{Na}]^{+}$, 933.2974; found, 933.2979

4-methylphenyl

$(2,3,5$-tri-O-acetyl- $\alpha$-D-arabinofuranosyl)-( $(1 \rightarrow 2)$-(3,5-di-O-benzyl- $\beta$-D-arabinofuranosyl)-( $1 \rightarrow 5)-2$ ,3-di-O-acetyl-1-thio- $\alpha$-D-arabinofuranoside (20)

The dried 11 (270 mg, $0.37 \mathrm{mmol}), 18(189 \mathrm{mg}, 0.56 \mathrm{mmol})$ and activated $4 \AA \mathrm{MS}(500 \mathrm{mg})$ were mixed together in anhydrous $\mathrm{Et}_{2} \mathrm{O}(6 \mathrm{~mL})$. The mixture was stirred for $1 \mathrm{~h}$ at $\mathrm{RT}^{-\mathrm{BF}_{3}} \cdot \mathrm{Et}_{2} \mathrm{O}(13 \mu \mathrm{L}$, $0.1 \mathrm{mmol}$ ) was added and the reaction was left for $1 \mathrm{~h}$ at $-30{ }^{\circ} \mathrm{C}$ before adding triethylamine and being filtered through Celite. After concentration the resulting crude product was purified by column chromatography twice (cyclohexane: ethyl acetate $=1: 1$ and DCM: ethyl acetate $=10: 1$ ). 20 (98 mg, 29\%) was gotten as white foam. $\mathrm{R}_{\mathrm{f}}=0.5$ (cyclohexane: ethyl acetate $=1: 1$ ). ${ }^{1} \mathrm{H}-\mathrm{NMR}\left(400 \mathrm{MHz}, \mathrm{CDCl}_{3}\right) \delta$ 7.40-7.38 (d, $\left.J=8.0 \mathrm{~Hz}, 2 \mathrm{H}\right), 7.30-7.25(\mathrm{~m}, 10 \mathrm{H}), 7.10-7.08(\mathrm{~d}, J$ $=7.9 \mathrm{~Hz}, 2 \mathrm{H}), 5.39\left(\mathrm{~s}, 1 \mathrm{H}, \mathrm{H}-1^{\text {Ara-A }}\right), 5.24(\mathrm{t}, J=5.2 \mathrm{~Hz}, 1 \mathrm{H}), 5.13(\mathrm{~d}, J=2.3 \mathrm{~Hz}, 1 \mathrm{H}), 5.10(\mathrm{~s}, 1 \mathrm{H}$, $\left.\mathrm{H}-1^{\text {Ara-C}}\right) ; 5.06-5.03(\mathrm{~m}, 2 \mathrm{H}), 5.00\left(\mathrm{~d}, J=3.5 \mathrm{~Hz}, \mathrm{H}-1^{\text {Ara-B }}\right), 4.70-4.44(\mathrm{~m}, 4 \mathrm{H}, \mathrm{Bn}), 4.43-4.33(\mathrm{~m}$, $3 \mathrm{H}), 4.22-4.04(\mathrm{~m}, 4 \mathrm{H}), 4.01-3.97\left(\mathrm{dd}, J_{1}=3.3 \mathrm{~Hz}, J_{2}=10.4 \mathrm{~Hz}, 1 \mathrm{H}\right), 3.66-3.55(\mathrm{~m}, 3 \mathrm{H}), 2.30(\mathrm{~s}$, 3H, Tol), 2.12 (s, 3H, Ac), 2.07 (s, 3H, Ac), 2.05 (s, 3H, Ac), 2.04 (s, 3H, Ac), 1.99 (s, 3H, Ac). ${ }^{13} \mathrm{C}$ NMR $\left(100 \mathrm{MHz}, \mathrm{CDCl}_{3}\right) \delta 170.44,170.21,169.79,169.73,169.66,138.20,138.16,138.08$, $132.79,129.82,129.68,128.33,128.32,127.67,127.56,127.55,127.47,106.93\left(\mathrm{C}-1^{\text {Ara-C }}\right), 101.45$ $\left(\mathrm{C}-1^{\text {Ara-B }}\right), 90.90\left(\mathrm{C}-1^{\text {Ara-A }}\right), 84.50,82.15,82.06,81.82,81.47,79.73,79.19,77.46,76.79,73.22$, 72.65, 72.03, 66.24, 63.03, 21.09, 20.77, 20.74, 20.70, 20.67, 20.57. HR ESI-TOF MS ( $\mathrm{m} / \mathrm{z}$ ): calcd for $\mathrm{C}_{46} \mathrm{H}_{54} \mathrm{O}_{17} \mathrm{SNa}[\mathrm{M}+\mathrm{Na}]^{+}$, 933.2974; found, 933.2978 


\section{3-Azidopropyl}

(2,3,5-tri-O-acetyl- $\alpha$-D-arabinofuranosyl)-( $(1 \rightarrow 2)-(3,5-d i-O-b e n z y l-\alpha-D-a r a b i n o f u r a n o s y l)-(1 \rightarrow 5)-($ 2,3-di-O-acetyl- $\alpha$-D-arabinofuranosyl)-( $(1 \rightarrow 6)-2,3,4$-tri-O-acetyl- $\alpha$-D-mannopyranoside (21)

The dried 19 ( $80 \mathrm{mg}, 0.088 \mathrm{mmol}), 9(52 \mathrm{mg}, 0.13 \mathrm{mmol})$ and activated $4 \AA \mathrm{MS}$ (200 mg) were mixed together in anhydrous DCM $(4 \mathrm{~mL})$ for $1 \mathrm{~h}$ at RT. The reaction was put at $-10{ }^{\circ} \mathrm{C}$ for $5 \mathrm{~min}$ before NIS and AgOTf were added. Upon for stirring at $-10{ }^{\circ} \mathrm{C}$ for $1 \mathrm{~h}$, the reaction was diluted with $\mathrm{CH}_{2} \mathrm{Cl}_{2}$, After filtering by Celite, the organic phase was washed with saturated aq. $\mathrm{Na}_{2} \mathrm{~S}_{2} \mathrm{O}_{3}$, water and dried over $\mathrm{MgSO}_{4}$, and then concentrated under reduced pressure. The residue was finally purified bysilica gel column chromatography with cyclohexane: ethyl acetate (2:3) as the eluent to afford $21(84 \mathrm{mg}, 82 \%)$ as foamy solid. $\mathrm{R}_{\mathrm{f}}=0.25$ (cyclohexane: ethyl acetate $\left.=1: 1\right) .{ }^{1} \mathrm{H}$ NMR (400 MHz, $\left.\mathrm{CDCl}_{3}\right) \delta 7.32-7.26(\mathrm{~m}, 10 \mathrm{H}), 5.30-5.28(\mathrm{~m}, 2 \mathrm{H}), 5.21-5.20(\mathrm{~m}, 1 \mathrm{H}), 5.11(\mathrm{~s}, 1 \mathrm{H}$, $\left.\mathrm{H}-1^{\text {Ara-A }}\right), 5.09-4.99(\mathrm{~m}, 4 \mathrm{H}), 5.05\left(\mathrm{~m}, 2 \mathrm{H}, \mathrm{H}-1^{\text {Ara-B }}, \mathrm{H}-1^{\text {Ara- }}\right), 4.80\left(\mathrm{~d}, J=1.6 \mathrm{~Hz}, 1 \mathrm{H}, \mathrm{H}-1^{\mathrm{Man}}\right)$, 4.59 (d, $J=11.8 \mathrm{~Hz}, 1 \mathrm{H}, \mathrm{Bn}), 4.58$ (d, $J=11.8 \mathrm{~Hz}, 1 \mathrm{H}, \mathrm{Bn}), 4.53$ (d, $J=11.8 \mathrm{~Hz}, 1 \mathrm{H}, \mathrm{Bn}), 4.52$ (d, $J=11.8 \mathrm{~Hz}, 1 \mathrm{H}, \mathrm{Bn}), 4.38-4.35(\mathrm{~m}, 1 \mathrm{H}), 4.27-4.19(\mathrm{~m}, 5 \mathrm{H}), 3.97-3.79(\mathrm{~m}, 5 \mathrm{H}), 3.71-3.49(\mathrm{~m}$, $5 \mathrm{H}$ ), $3.41(\mathrm{t}, J=6.6 \mathrm{~Hz}, 2 \mathrm{H}), 2.14$ (s, 3H, Ac), 2.09 (s, 3H, Ac), 2.09 (s, 3H, Ac), 2.07 (s, 3H, Ac), 2.05 (s, 3H, Ac), 2.02 (s, 3H, Ac), 2.00 (s, 3H, Ac), 1.98 (s, 3H, Ac), 1.89-1.86 (m, $\left.2 \mathrm{H}, \mathrm{CH}_{2}\right) .{ }^{13} \mathrm{C}$ NMR $\left(100 \mathrm{MHz}, \mathrm{CDCl}_{3}\right) \delta 170.47,170.09,170.07,169.95,169.68,169.64,169.57,138.08$, 137.77, 128.32, 127.75, $106.56\left(\mathrm{C}-1^{\text {Ara-C}}\right), 105.31\left(\mathrm{C}-1^{\text {Ara-B }}\right), 105.25\left(\mathrm{C}-1^{\text {Ara-A }}\right), 97.46,86.59,83.11$, $81.76,81.44,81.39,80.79,80.46,76.88,73.33,72.05,69.64,69.52,69.31,69.27,66.52,66.05$, $65.45,64.72,63.12,48.17,28.70,20.86,20.74,20.72,20.70$. HR ESI-TOF MS $(\mathrm{m} / \mathrm{z})$ : calcd for $\mathrm{C}_{54} \mathrm{H}_{69} \mathrm{~N}_{3} \mathrm{O}_{26} \mathrm{Na}[\mathrm{M}+\mathrm{Na}]^{+}, 1198.4062$; found, 1198.4057 .

\section{3-Azidopropyl}

(2,3,5-tri-O-acetyl- $\alpha$-D-arabinofuranosyl)-( $1 \rightarrow 2)-(3,5$-di-O-benzyl- $\beta$-D-arabinofuranosyl)-( $1 \rightarrow 5)-($ 2,3-di-O-acetyl- $\alpha$-D-arabinofuranosyl)-( $1 \rightarrow 6)$-2,3,4-tri-O-acetyl- $\alpha$-D-mannopyranoside (22)

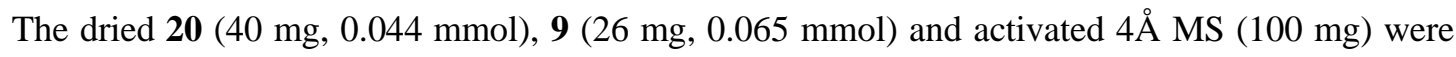
mixed together in anhydrous DCM $(3 \mathrm{~mL})$ for $1 \mathrm{~h}$ at RT. The reaction was put at $-10{ }^{\circ} \mathrm{C}$ for $5 \mathrm{~min}$ before NIS and AgOTf were added. Upon for stirring at $-10{ }^{\circ} \mathrm{C}$ for $1 \mathrm{~h}$, the reaction was diluted with $\mathrm{CH}_{2} \mathrm{Cl}_{2}$, After filtering by Celite, the organic phase was washed with saturated aq. $\mathrm{Na}_{2} \mathrm{~S}_{2} \mathrm{O}_{3}$, water and dried over $\mathrm{MgSO}_{4}$, and then concentrated under reduced pressure. The residue was finally purified bysilica gel column chromatography with cyclohexane: ethyl acetate (2:3) as the eluent to afford 21 (43 mg, 84\%) as foamy solid. $R_{\mathrm{f}}=0.25$ (cyclohexane: ethyl acetate $\left.=1: 1\right) .{ }^{1} \mathrm{H}$ NMR (400 MHz, $\left.\mathrm{CDCl}_{3}\right)$ $\delta$ 7.43-7.26 (m, 10H, Ph), 5.20-5.10 (m, 3H ), 5.34-5.30 (m, 2H), $5.08(\mathrm{~s}$, $\left.1 \mathrm{H}, \mathrm{H}-1^{\text {Ara-C }}\right), 5.03\left(\mathrm{dd}, J_{1}=1.8 \mathrm{~Hz}, J_{2}=6.7 \mathrm{~Hz}, 1 \mathrm{H}\right), 4.99(\mathrm{~d}, J=3.3 \mathrm{~Hz}, 1 \mathrm{H}), 4.95(\mathrm{~s}, 1 \mathrm{H}$, H-1 $\left.{ }^{\text {Ara-B }}\right), 4.87(\mathrm{~d}, J=4.3 \mathrm{~Hz}, 1 \mathrm{H}), 4.81\left(\mathrm{~d}, J=1.3 \mathrm{~Hz}, 1 \mathrm{H}, \mathrm{H}-1^{\mathrm{Man}}\right), 4.65-4.52(\mathrm{~m}, 4 \mathrm{H}, \mathrm{Bn})$, 4.50-4.36 (m, 2H), 5.23-3.99 (m, 6H), 3.88-3.76 (m, 3H), 3.62-3.49 (m, 5H), $3.41(\mathrm{t}, J=6.5 \mathrm{~Hz}$, $2 \mathrm{H}, \mathrm{CH}_{2}$ ), 2.13 (s, 3H, Ac), 2.12 (s, 3H, Ac), 2.09 (s, 3H, Ac), 2.07 (s, 3H, Ac), 2.07 (s, 3H, Ac), 1.98 (s, 3H, Ac), 1.97 (s, 3H, Ac), 1.96 (s, 3H, Ac), 1.89-1.85 (m, 2H, $\left.\mathrm{CH}_{2}\right) .{ }^{13} \mathrm{C} \mathrm{NMR} \mathrm{(100} \mathrm{MHz,}$ $\left.\mathrm{CDCl}_{3}\right) \delta 170.50,170.15,170.05,170.00,169.94,169.74,169.58,169.50,138.30,138.14,128.36$, 128.31, 127.67, 127.47, $106.92\left(\mathrm{C}-1^{\text {Ara-C }}\right), 105.38\left(\mathrm{C}-1^{\text {Ara-B }}\right), 101.44\left(\mathrm{C}-1^{\text {Ara-A }}\right), 97.52\left(\mathrm{C}-1^{\mathrm{Man}}\right)$, $84.73,82.60,82.23,82.09,80.68,79.65,79.15,73.24,72.68,71.86,69.64,69.36,69.33,66.95$, $66.30,65.11,64.74,62.79,48.11,28.68,20.80,20.75,20.70,20.67,20.58,20.56$. HR ESI-TOF MS $(m / z)$ : calcd for $\mathrm{C}_{54} \mathrm{H}_{69} \mathrm{~N}_{3} \mathrm{O}_{26} \mathrm{Na}[\mathrm{M}+\mathrm{Na}]^{+}, 1198.4062$; found, 1198.4059 . 
4-methylphenyl

(2,3,5-tri-O-acetyl- $\alpha$-D-arabinofuranosyl)-( $1 \rightarrow 2)$-3,4,6-tri-O-benzyl-1-thio- $\alpha$-D-mannopyranoside (24)

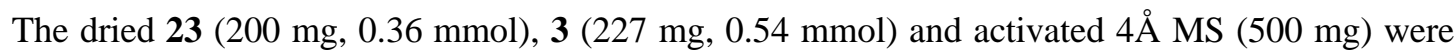
mixed together in anhydrous DCM $(6 \mathrm{~mL})$. The mixture was stirred for $1 \mathrm{~h}$ at RT under argon then cooled to $-50{ }^{\circ} \mathrm{C} . \mathrm{BF}_{3} \cdot \mathrm{Et}_{2} \mathrm{O}(77 \mu \mathrm{L}, 0.54 \mathrm{mmol})$ was added and the reaction was left for $20 \mathrm{~min}$ at $-50{ }^{\circ} \mathrm{C}$ before adding triethylamine and being filtered through Celite. After concentration the resulting crude product was purified by column chromatography (cyclohexane: ethyl acetate $=3: 1$ ) getting compound $24(263 \mathrm{mg}, 90 \%)$ as colorless syrup. $\mathrm{R}_{\mathrm{f}}=0.5$ (cyclohexane: ethyl acetate $=$ 2:1). ${ }^{1} \mathrm{H}$ NMR $\left(400 \mathrm{MHz}, \mathrm{CDCl}_{3}\right) \delta$ 7.27-7.18 (m, 13H, Ph), 7.12-7.09 (m, 2H, Ph), 5.23 (s, 1H, $\left.\mathrm{H}-1^{\text {Ara }}\right), 5.21-5.14(\mathrm{~m}, 3 \mathrm{H}), 4.83\left(\mathrm{dd}, J_{1}=1.7 \mathrm{~Hz}, J_{2}=5.3 \mathrm{~Hz}, 1 \mathrm{H}\right), 4.82(\mathrm{~d}, J=1.60 \mathrm{~Hz}, 1 \mathrm{H}$, H-1 $\left.{ }^{\text {Man-B }}\right), 4.77(\mathrm{~d}, J=11 \mathrm{~Hz}, 1 \mathrm{H}), 4.69\left(\mathrm{~d}, J=1.40 \mathrm{~Hz}, 1 \mathrm{H}, \mathrm{H}-1^{\text {Man-A }}\right), 4.61-4.50(\mathrm{~m}, 6 \mathrm{H}, \mathrm{Bn})$, $4.35-4.11(\mathrm{~m}, 3 \mathrm{H}), 4.00(\mathrm{~s}, 1 \mathrm{H}), 3.84-3.63(\mathrm{~m}, 8 \mathrm{H}), 3.46\left(\mathrm{dd}, J_{1}=2.4 \mathrm{~Hz}, J_{2}=10.9 \mathrm{~Hz}, 1 \mathrm{H}\right)$, 3.43-3.29 (m, 3H), 2.03 (s, 3H, Ac), 2.02 (s, 3H, Ac), 1.96 (s, 3H, Ac), 1.94 (s, 3H, Ac), 1.92 (s, $3 \mathrm{H}, \mathrm{Ac}), 1.89$ (s, 3H, Ac), 1.80-1.74 (m, 2H, $\left.\mathrm{CH}_{2}\right) .{ }^{13} \mathrm{C} \mathrm{NMR}\left(100 \mathrm{MHz}, \mathrm{CDCl}_{3}\right) \delta 170.52,170.20$, $170.05,169.93$, 169.62, 169.30, 138.50, 138.44, 138.31, 128.34, 128.26, 127.90, 127.73, 127.57, 127.54, 127.42, $106.82\left(\mathrm{C}-1^{\text {Ara }}\right), 99.19\left(\mathrm{C}-1^{\text {Man-B }}\right), 97.45\left(\mathrm{C}-1^{\text {Man-A }}\right), 81.16,80.30,79.96,74.98$, $74.60,73.93,73.27,72.24,71.91,69.62,69.39,69.23,66.71,66.06,64.68,63.05,48.14,28.63$, 20.84, 20.77, 20.76, 20.71, 20.62. HR ESI-TOF MS $(\mathrm{m} / \mathrm{z})$ : calcd for $\mathrm{C}_{45} \mathrm{H}_{50} \mathrm{O}_{12} \mathrm{SNa}[\mathrm{M}+\mathrm{Na}]^{+}$, 837.2915; found, 837.2918

Cyanomethyl

$(2,3,5$-tri-O-acetyl- $\alpha$-D-arabinofuranosyl)-( $1 \rightarrow 2)$-(3,4,6-tri-O-benzyl- $\alpha$-D-mannopyranosyl)-( $1 \rightarrow 6$ ) -2,3,4-tri-O-acetyl-1-thio- $\alpha$-D-mannopyranoside (28)

To a solution of $24(260 \mathrm{mg}, 0.32 \mathrm{mmol})$ in $7 \mathrm{~mL}$ wet $\mathrm{CH}_{2} \mathrm{Cl}_{2}$ (containing $20 \% \mathrm{H}_{2} \mathrm{O}$ ) was added NIS (144 mg, $0.64 \mathrm{mmol})$, AgOTf ( $82 \mathrm{mg}, 0.32 \mathrm{mmol})$ and TTBP (238 mg, $2.58 \mathrm{mmol})$. The solution was stirred for $1 \mathrm{~h}$ until no 24 left. The solution was diluted with $\mathrm{CH}_{2} \mathrm{Cl}_{2}$, and after filtering by Celite, the organic phase was washed with saturated aq. $\mathrm{Na}_{2} \mathrm{~S}_{2} \mathrm{O}_{3}$, water and dried over $\mathrm{MgSO}_{4}$, then concentrated under reduced pressure. The crude was purified by column chromatography (cyclohexane: ethyl acetate $=3: 2)$ to give $\mathbf{2 5}(192 \mathrm{mg}, 85 \%)$ as colorless syrup. $\mathrm{R}_{\mathrm{f}}=0.25$ (cyclohexane: ethyl acetate $=3: 2$ ). All the $\mathbf{2 5}$ was immediately put into $3 \mathrm{~mL}$ dry DCM under argon and then $\mathrm{CCl}_{3} \mathrm{CN}(270 \mu \mathrm{L}, 2.7 \mathrm{mmol})$ and $\mathrm{DBU}(41 \mu \mathrm{L}, 0.27 \mathrm{mmol})$ were added to the solution at ice bath. The solution was stirred for $1 \mathrm{~h}$ at $0{ }^{\circ} \mathrm{C}$ and solution was removed under vacuo and purified by column chromatography with $1 \%$ triethylamine added cyclohexane/ethyl acetate (2/1). 26 (207 mg, 90\%) was gotten as colorless syrup. $\mathrm{R}_{\mathrm{f}}=0.5$ (cyclohexane: ethyl acetate $=3: 2$ ). 26 should be used without delay for its poor stability. The dried 26 (50 mg, $0.058 \mathrm{mmol})$, 27 (33 mg, $0.09 \mathrm{mmol})$ and activated $4 \AA \mathrm{MS}(200 \mathrm{mg})$ were mixed together in $3 \mathrm{~mL}$ anhydrous $\mathrm{Et}_{2} \mathrm{O}$ and DCM solution (15:1). The mixture was stirred for $1 \mathrm{~h}$ at $\mathrm{RT}$ under argon then cooled to $-30{ }^{\circ} \mathrm{C}$. Then $\mathrm{BF}_{3} \cdot \mathrm{Et}_{2} \mathrm{O}(26 \mu \mathrm{L}, 0.18 \mathrm{mmol})$ was added and the reaction was left for $3 \mathrm{~h}$ at $-30{ }^{\circ} \mathrm{C}$ before being quenched with triethylamine. After Celite filter and concentration the resulting crude product was purified by column chromatography (cyclohexane: ethyl acetate $=1: 1$ ) getting compound $28(28 \mathrm{mg}, 45 \%)$ as colorless syrup. $\mathrm{R}_{\mathrm{f}}=0.4$ (cyclohexane: ethyl acetate $\left.=3: 2\right) .{ }^{1} \mathrm{H}$ NMR (400 MHz, $\left.\mathrm{CDCl}_{3}\right) \delta$ 7.28-7.18 (m, 13H, Ph), 7.15-7.12 (m, 2H, Ph), $5.34(\mathrm{~d}, J=1.1 \mathrm{~Hz}, 1 \mathrm{H}$, $\left.\mathrm{H}-1^{\text {Man-A }}\right), 5.28\left(\mathrm{dd}, J_{1}=1.5 \mathrm{~Hz}, J_{2}=3.4 \mathrm{~Hz}, 1 \mathrm{H}\right), 5.24\left(\mathrm{~s}, 1 \mathrm{H}, \mathrm{H}-1^{\text {Ara }}\right), 5.21-5.20(\mathrm{~m}, 1 \mathrm{H})$, 5.13-5.10 (m, 1H), $4.91\left(\mathrm{dd}, J_{1}=1.6 \mathrm{~Hz}, J_{2}=5.2 \mathrm{~Hz}, 1 \mathrm{H}\right), 4.83\left(\mathrm{~d}, J=1.7 \mathrm{~Hz}, \mathrm{H}-1^{\text {Man-B }}\right), 4.79(\mathrm{~d}, J$ 
$=11 \mathrm{~Hz}, 1 \mathrm{H}), 4.64-4.43(\mathrm{~m}, 6 \mathrm{H}, \mathrm{Bn}), 4.43\left(\mathrm{dd}, J_{1}=3.7 \mathrm{~Hz}, J_{2}=11.8 \mathrm{~Hz}, 1 \mathrm{H}\right), 4.23-4.12(\mathrm{~m}, 3 \mathrm{H})$, $4.00(\mathrm{t}, J=2.2 \mathrm{~Hz}, 1 \mathrm{H}), 3.84-3.75(\mathrm{~m}, 3 \mathrm{H}), 3.52\left(\mathrm{dd}, J_{1}=2.3 \mathrm{~Hz}, J_{2}=11.2 \mathrm{~Hz}, 1 \mathrm{H}\right), 3.25(\mathrm{~d}, J=$ $\left.16.9 \mathrm{~Hz}, 1 \mathrm{H}, \mathrm{CH}_{2}\right), 3.05$ (d, $\left.J=16.9 \mathrm{~Hz}, 1 \mathrm{H}, \mathrm{CH}_{2}\right), 2.06$ (s, 3H, Ac), 2.03 (s, 3H, Ac), 1.98 (s, 3H, Ac), 1.96 (s, 3H, Ac), 1.93 (s, 3H, Ac), 1.90 (s, 3H, Ac). ${ }^{13} \mathrm{C}$ NMR (100 MHz, $\mathrm{CDCl}_{3}$ ) $\delta$ 170.56, $170.21,169.78,169.66,169.46,169.30,138.46,128.38,128.36,128.28,127.88,127.74,127.59$, 127.55, 127.47, 115.69, $106.84\left(\mathrm{C}-1^{\text {Ara }}\right), 99.17\left(\mathrm{C}-1^{\text {Man-B }}\right), 82.00\left(\mathrm{C}-1^{\text {Man-A }}\right), 81.12,80.36,79.55$, $74.97,74.52,73.83,73.28,72.07,72.00,70.62,69.64,69.42,69.20,66.42,65.63,63.02,20.80$, 20.73, 20.69, 20.63, 20.57, 15.30. HR ESI-TOF MS $(\mathrm{m} / z)$ : calcd for $\mathrm{C}_{52} \mathrm{H}_{61} \mathrm{NO}_{20} \mathrm{SNa}[\mathrm{M}+\mathrm{Na}]^{+}$ 1074.3400; found, 1074.3403

3-Azidopropyl

$(2,3,5$-tri-O-acetyl- $\alpha$-D-arabinofuranosyl)-( $1 \rightarrow 2)$-(3,4,6-tri-O-benzyl- $\alpha$-D-mannopyranosyl)-( $1 \rightarrow 6)$ -2,3,4-tri-O-acetyl- $\alpha$-D-mannopyranoside (29)

The dried 26 (50 mg, $0.058 \mathrm{mmol}), 9$ (35 mg, $0.09 \mathrm{mmol}$ ) and activated 4 $\mathrm{AS}$ (200 mg) were mixed together in $3 \mathrm{~mL}$ anhydrous DCM. The mixture was stirred for $1 \mathrm{~h}$ at RT under argon then cooled to $-30{ }^{\circ} \mathrm{C}$. Then $\mathrm{BF}_{3} \cdot \mathrm{Et}_{2} \mathrm{O}(26 \mu \mathrm{L}, 0.18 \mathrm{mmol})$ was added and the reaction was left for $3 \mathrm{~h}$ at $-30{ }^{\circ} \mathrm{C}$ before being quenched with triethylamine. After Celite filter and concentration the resulting crude product was purified by column chromatography twice (cyclohexane: ethyl acetate $=1: 1)$ getting compound $29(47 \mathrm{mg}, 75 \%)$ as colorless syrup. $\mathrm{R}_{\mathrm{f}}=0.6$ (cyclohexane: ethyl acetate $=1: 1) .{ }^{1} \mathrm{H}$ NMR $\left(400 \mathrm{MHz}, \mathrm{CDCl}_{3}\right) \delta$ 7.27-7.18 (m, 13H, Ph), 7.12-7.09 (m, 2H, Ph), 5.23 (s, 1H, H-1 $\left.{ }^{\text {Ara }}\right), 5.21-5.14(\mathrm{~m}, 3 \mathrm{H}), 4.83\left(\mathrm{dd}, J_{1}=1.7 \mathrm{~Hz}, J_{2}=5.3 \mathrm{~Hz}, 1 \mathrm{H}\right), 4.82(\mathrm{~d}, J=1.60 \mathrm{~Hz}, 1 \mathrm{H}$, H-1 $\left.{ }^{\text {Man-B }}\right), 4.77$ (d, $\left.J=11 \mathrm{~Hz}, 1 \mathrm{H}\right), 4.69\left(\mathrm{~d}, J=1.40 \mathrm{~Hz}, 1 \mathrm{H}, \mathrm{H}-1^{\text {Man-A }}\right), 4.61-4.50$ (m, 6H, Bn), $4.35-4.11(\mathrm{~m}, 3 \mathrm{H}), 4.00(\mathrm{~s}, 1 \mathrm{H}), 3.84-3.63(\mathrm{~m}, 8 \mathrm{H}), 3.46\left(\mathrm{dd}, J_{1}=2.4 \mathrm{~Hz}, J_{2}=10.9 \mathrm{~Hz}, 1 \mathrm{H}\right)$, 3.43-3.29 (m, 3H), 2.03 (s, 3H, Ac), 2.02 (s, 3H, Ac), 1.96 (s, 3H, Ac), 1.94 (s, 3H, Ac), 1.92 (s, $3 \mathrm{H}, \mathrm{Ac}), 1.89$ (s, 3H, Ac), 1.80-1.74 (m, 2H, $\left.\mathrm{CH}_{2}\right) .{ }^{13} \mathrm{C} \mathrm{NMR}\left(100 \mathrm{MHz}, \mathrm{CDCl}_{3}\right) \delta 170.52,170.20$, $170.05,169.93,169.62,169.30,138.50,138.44,138.31,128.34,128.26,127.90,127.73,127.57$,

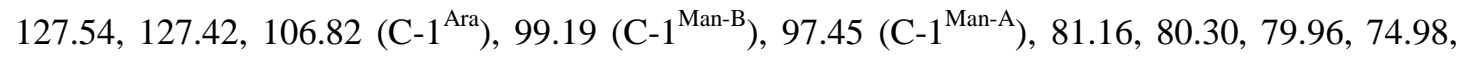
$74.60,73.93,73.27,72.24,71.91,69.62,69.39,69.23,66.71,66.06,64.68,63.05,48.14,28.63$, 20.84, 20.77, 20.76, 20.71, 20.62. HR ESI-TOF MS $(\mathrm{m} / z)$ : calcd for $\mathrm{C}_{53} \mathrm{H}_{65} \mathrm{~N}_{3} \mathrm{O}_{21} \mathrm{Na}[\mathrm{M}+\mathrm{Na}]^{+}$, 1102.4003; found, 1102.4009 .

3-Aminopropyl $\alpha$-D-arabinofuranosyl-(1 $\rightarrow 2)-\alpha$-D-arabinofuranosyl-(1 $\rightarrow 6)-\alpha$-D-mannopyranoside (30)

To a solution of compound $12(45 \mathrm{mg})$ in THF $(4 \mathrm{~mL})$ and methanol $(0.1 \mathrm{~mL})$, liquid $\mathrm{NH}_{3}(8 \mathrm{~mL})$ was added at $-60{ }^{\circ} \mathrm{C}$, a piece of sodium was added quickly until the solution became dark blue. After $30 \mathrm{~min}$, few drops of water was added to the solution to quench the reaction. And the crude was evaporated and resolve in water. Then resin was added to the solution until $\mathrm{pH}$ reached 7. After that the resin was filtered and washed by $1 \mathrm{M} \mathrm{NH} \mathrm{N}_{3} \cdot \mathrm{H}_{2} \mathrm{O}(50 \mathrm{~mL} * 3)$. The $\mathrm{NH}_{3} \cdot \mathrm{H}_{2} \mathrm{O}$ was collected and evaporated to give the crude. Finally, the crude was purified by LH-20 in methanol to give $30(15 \mathrm{mg}, 59 \%)$ as write foam. ${ }^{1} \mathrm{H}$ NMR $\left(400 \mathrm{MHz}, \mathrm{D}_{2} \mathrm{O}\right) \delta 5.12\left(\mathrm{~s}, 2 \mathrm{H}, \mathrm{H}-1^{\text {Ara-A }}\right.$, $\left.\mathrm{H}-1^{\text {Ara-B }}\right), 4.80\left(\mathrm{~s}, 1 \mathrm{H}, \mathrm{H}-1^{\mathrm{Man}}\right), 4.12-3.53(\mathrm{~m}, 18 \mathrm{H}), 3.07-2.85\left(\mathrm{~m}, 2 \mathrm{H}, \mathrm{CH}_{2}\right), 1.84-1.72(\mathrm{~m}, 2 \mathrm{H}$, $\left.\mathrm{CH}_{2}\right) .{ }^{13} \mathrm{C}$ NMR $\left(100 \mathrm{MHz}, \mathrm{D}_{2} \mathrm{O}\right) \delta 107.24\left(\mathrm{C}-1^{\text {Ara-A }}\right), 106.31\left(\mathrm{C}-1^{\text {Ara-B }}\right), 99.85\left(\mathrm{C}-1^{\mathrm{Man}}\right), 87.17$, 84.11, 83.12, 81.27, 76.50, 75.10, 71.29, 70.59, 69.96, 66.73, 65.87, 61.14, 60.84, 38.43, 29.30, 23.29. HR ESI-TOF MS $(\mathrm{m} / z)$ : calcd for $\mathrm{C}_{19} \mathrm{H}_{34} \mathrm{NO}_{14} \mathrm{H}[\mathrm{M}+\mathrm{H}]^{+}$, 502.2130; found, 502.2128 
3-Aminopropyl $\quad \alpha$-D-arabinofuranosyl-( $1 \rightarrow 2)$ - $\alpha$-D-mannopyranosyl-( $1 \rightarrow 6)$ - $\alpha$-D-mannopyranoside (31)

To a solution of compound $29(47 \mathrm{mg})$ in THF $(4 \mathrm{~mL})$ and methanol $(0.1 \mathrm{~mL})$, liquid $\mathrm{NH}_{3}(8 \mathrm{~mL})$ was added at $-60{ }^{\circ} \mathrm{C}$, a piece of sodium was added quickly until the solution became dark blue. After $30 \mathrm{~min}$, few drop of water was added to the solution to quench the reaction. And the crude was evaporated and resolve in water. Then resin was added to the solution until $\mathrm{pH}$ reached 7. After that the resin was filtered and washed by $1 \mathrm{M} \mathrm{NH} \mathrm{N}_{3} \cdot \mathrm{H}_{2} \mathrm{O}(50 \mathrm{~mL} * 3)$. The $\mathrm{NH}_{3} \cdot \mathrm{H}_{2} \mathrm{O}$ was collected and evaporated to give the crude. Finally, the crude was purified by LH-20 in methanol to give $31(12 \mathrm{mg}, 53 \%)$ as write foam. ${ }^{1} \mathrm{H}$ NMR $\left(400 \mathrm{MHz}, \mathrm{D}_{2} \mathrm{O}\right) \delta 5.10(\mathrm{~d}, J=1.6 \mathrm{~Hz}, 1 \mathrm{H}$, $\left.\mathrm{H}-1^{\text {Ara }}\right), 4.97\left(\mathrm{~s}, 1 \mathrm{H}, \mathrm{H}-1^{\text {Man-A }}\right), 4.79\left(\mathrm{~s}, 1 \mathrm{H}, \mathrm{H}-1^{\text {Man-B }}\right), 4.15-4.13(\mathrm{~m}, 1 \mathrm{H}), 4.05-4.03(\mathrm{~m}, 1 \mathrm{H})$, 3.95-3.47 (m, 20H), 3.05-3.02 (m, 2H, $\left.\mathrm{CH}_{2}\right), 1.73-1.70\left(\mathrm{~m}, 2 \mathrm{H}, \mathrm{CH}_{2}\right) .{ }^{13} \mathrm{C} \mathrm{NMR}\left(100 \mathrm{MHz}, \mathrm{D}_{2} \mathrm{O}\right)$ $\delta 109.38\left(\mathrm{C}-1^{\text {Ara }}\right), 99.99\left(\mathrm{C}-1^{\text {Man-A }}\right), 98.74\left(\mathrm{C}-1^{\text {Man-B }}\right), 83.58,81.23,77.47,76.47,72.68,71.05$, $70.27,66.84,65.88,61.10,60.75,38.43,29.31,26.11$. HR ESI-TOF MS $(\mathrm{m} / z)$ : calcd for $\mathrm{C}_{20} \mathrm{H}_{37} \mathrm{NO}_{15} \mathrm{Na}[\mathrm{M}+\mathrm{Na}]^{+}$, 554.2055; found 554.2052

\title{
3-Aminopropyl
}

$\alpha$-D-arabinofuranosyl-( $1 \rightarrow 2)$ - $\alpha$-D-arabinofuranosyl-( $(1 \rightarrow 5)-\alpha$-D-arabinofuranosyl-( $(1 \rightarrow 6)-\alpha-D-m a n n$ opyranoside (32)

To a solution of compound $21(42 \mathrm{mg})$ in THF $(4 \mathrm{~mL})$ and methanol $(0.1 \mathrm{~mL})$, liquid $\mathrm{NH}_{3}(8 \mathrm{~mL})$ was added at $-60{ }^{\circ} \mathrm{C}$, a piece of sodium was added quickly until the solution became dark blue. After $30 \mathrm{~min}$, few drops of water were added to the solution to quench the reaction. And the crude was evaporated and resolve in water. Then resin was added to the solution until $\mathrm{pH}$ reached 7. After that the resin was filtered and washed by $1 \mathrm{M} \mathrm{NH} \mathrm{N}_{3} \cdot \mathrm{H}_{2} \mathrm{O}(50 \mathrm{~mL} * 3)$. The $\mathrm{NH}_{3} \cdot \mathrm{H}_{2} \mathrm{O}$ was collected and evaporated to give the crude. Finally, the crude was purified by LH-20 in methanol to give $32(12 \mathrm{mg}, 55 \%)$ as write foam. ${ }^{1} \mathrm{H}$ NMR $\left(400 \mathrm{MHz}, \mathrm{D}_{2} \mathrm{O}\right) \delta 5.05\left(\mathrm{~s}, 1 \mathrm{H}, \mathrm{H}-1^{\text {Ara-C }}\right), 5.04(\mathrm{~s}$, $\left.1 \mathrm{H}, \mathrm{H}-1^{\text {Ara-B }}\right), 4.93\left(\mathrm{~d}, J=1.5 \mathrm{~Hz}, \mathrm{H}-1^{\text {Ara-A }}\right), 4.70\left(\mathrm{~s}, 1 \mathrm{H}, \mathrm{H}-1^{\mathrm{Man}}\right), 4.10-4.05(\mathrm{~m}, 1 \mathrm{H}), 4.02-3.91(\mathrm{~m}$, $6 \mathrm{H})$, 3.88-3.78 (m, 4H), 3.76-3.56 (m, $11 \mathrm{H}), 3.50-3.40(\mathrm{~m}, 1 \mathrm{H}), 2.99-2.89\left(\mathrm{~m}, 2 \mathrm{H}, \mathrm{CH}_{2}\right)$, 1.72-1.60 (m, 2H, $\left.\mathrm{CH}_{2}\right) .{ }^{13} \mathrm{C}$ NMR $\left(100 \mathrm{MHz}, \mathrm{D}_{2} \mathrm{O}\right) \delta 107.46\left(\mathrm{C}-1^{\text {Ara-C }}\right), 107.23\left(\mathrm{C}-1^{\text {Ara-B }}\right), 106.29$ $\left(\mathrm{C}-1^{\text {Ara-A }}\right), 99.91$ (C-1 $\left.{ }^{\text {Man }}\right), 87.08,84.07,83.19,82.13,82.06,81.27,80.78,76.67,76.47,75.08$, $71.17,71.12,70.58,70.04,69.96,66.96,66.75,66.67,66.57,65.75,65.50,61.12,60.83,38.35$, 29.27, 23.29. HR ESI-TOF MS $(\mathrm{m} / \mathrm{z})$ : calcd for $\mathrm{C}_{24} \mathrm{H}_{43} \mathrm{NO}_{18} \mathrm{H}[\mathrm{M}+\mathrm{H}]^{+}, 634.2553$; found 634.2552

\author{
3-Aminopropyl \\ $\alpha$-D-arabinofuranosyl-( $1 \rightarrow 2)-\beta$-D-arabinofuranosyl-( $1 \rightarrow 5)-\alpha$-D-arabinofuranosyl-( $(1 \rightarrow 6)-\alpha$-D-mann \\ opyranoside (33)
}

To a solution of compound $22(43 \mathrm{mg})$ in THF $(4 \mathrm{~mL})$ and methanol $(0.1 \mathrm{~mL})$, liquid $\mathrm{NH}_{3}(8 \mathrm{~mL})$ was added at $-60{ }^{\circ} \mathrm{C}$, a piece of sodium was added quickly until the solution became dark blue. After $30 \mathrm{~min}$, few drops of water were added to the solution to quench the reaction. And the crude was evaporated and resolve in water. Then resin was added to the solution until $\mathrm{pH}$ reached 7. After that the resin was filtered and washed by $1 \mathrm{M} \mathrm{NH} \cdot \mathrm{H}_{2} \mathrm{O}(50 \mathrm{~mL} * 3)$. The $\mathrm{NH}_{3} \cdot \mathrm{H}_{2} \mathrm{O}$ was collected and evaporated to give the crude. Finally, the crude was purified by LH-20 in methanol to give 33 (12 mg, 54\%) as write foam. ${ }^{1} \mathrm{H}$ NMR $\left(400 \mathrm{MHz}, \mathrm{D}_{2} \mathrm{O}\right) \delta 5.01-4.99\left(\mathrm{~m}, 2 \mathrm{H}, \mathrm{H}-1^{\text {Ara-C }}\right.$, $\left.\mathrm{H}-1^{\text {Ara-A }}\right), 4.92\left(\mathrm{~d}, J=1.5 \mathrm{~Hz}, 1 \mathrm{H}, \mathrm{H}-1^{\text {Ara-B }}\right), 4.70\left(\mathrm{~s}, 1 \mathrm{H}, \mathrm{H}-1^{\text {Man }}\right), 3.08-3.04(\mathrm{~m}, 3 \mathrm{H}), 3.99-3.94(\mathrm{~m}$, $3 \mathrm{H})$, 3.85-3.77 (m, 3H), 3.85-3.77 (m, 6H), 3.70-3.42 (m, 11H), 2.96-2.85 (m, $\left.2 \mathrm{H}, \mathrm{CH}_{2}\right)$, 
1.70-1.62 (m, 2H, $\left.\mathrm{CH}_{2}\right) .{ }^{13} \mathrm{C}$ NMR (100 MHz, D $\left.2 \mathrm{O}\right) \delta 108.72\left(\mathrm{C}-1^{\text {Ara-C }}\right), 107.57\left(\mathrm{C}-1^{\text {Ara-A }}\right), 101.25$ $\left(\mathrm{C}-1^{\text {Ara-B }}\right), 99.93\left(\mathrm{C}-1^{\mathrm{Man}}\right), 83.64,82.99,82.71,82.63,81.42,81.21,80.68,80.65,77.03,76.69$, 72.92, 71.20, 71.13, 70.60, 70.07, 69.97, 68.34, 68.29, 66.80, 66.69, 66.57, 66.50, 65.78, 63.07, 61.01, 38.39, 29.31. HR ESI-TOF MS (m/z): calcd for $\mathrm{C}_{24} \mathrm{H}_{43} \mathrm{NO}_{18} \mathrm{H}[\mathrm{M}+\mathrm{H}]^{+}, 634.2553$; found 634.2556

3-Aminopropyl

$\alpha$-D-arabinofuranosyl-( $1 \rightarrow 2)$ - $\alpha$-D-arabinofuranosyl-( $1 \rightarrow 6)-\alpha$-D-mannopyranosyl-( $1 \rightarrow 6)-\alpha$-D-mann opyranoside (34)

To a solution of Compound 15' $(15 \mathrm{mg})$ in THF (2 mL) and methanol $(0.05 \mathrm{~mL})$, liquid $\mathrm{NH}_{3}(4$ $\mathrm{mL}$ ) was added at $-60{ }^{\circ} \mathrm{C}$, a piece of sodium was added quickly until the solution became dark blue. After $30 \mathrm{~min}$, few drops of water was added to the solution to quench the reaction. And the crude was evaporated and resolve in water. Then resin was added to the solution until $\mathrm{pH}$ reached 7. After that the resin was filtered and washed by $1 \mathrm{M} \mathrm{NH} \mathrm{N}_{3} \cdot \mathrm{H}_{2} \mathrm{O}(25 \mathrm{~mL} * 3)$. The $\mathrm{NH}_{3} \cdot \mathrm{H}_{2} \mathrm{O}$ was collected and evaporated to give the crude. Finally, the crude was purified by LH-20 in methanol to give 34 (4.2 mg, 55\%) as write foam. ${ }^{1} \mathrm{H}$ NMR (400 MHz, $\left.\mathrm{D}_{2} \mathrm{O}\right) \delta 5.16\left(\mathrm{~s}, 1 \mathrm{H}, \mathrm{H}-1^{\text {Ara-B }}\right), 5.15(\mathrm{~s}$, $\left.1 \mathrm{H}, \mathrm{H}-1^{\text {Ara-A }}\right), 4.86$ (s, 1H, H-1 $\left.{ }^{\text {Man-A }}\right), 4.82$ (s, 1H, H-1 $\left.{ }^{\text {Man-B }}\right), 4.13$ (s, 1H), 4.08-4.03 (m, 4H), 3.95-3.91 (m, 6H), 3.82-3.65 (m, 17H), 3.07-3.04 (m, 2H, $\left.\mathrm{CH}_{2}\right), 2.02-1.74\left(\mathrm{~m}, 2 \mathrm{H}, \mathrm{CH}_{2}\right) .{ }^{13} \mathrm{C}$ NMR (100 MHz, D 20$) \delta 107.15\left(C-1^{\text {Ara-B }}\right), 106.26\left(C-1^{\text {Ara-A }}\right), 100.00\left(C-1^{\text {Man-A }}\right), 99.58\left(C-1^{\text {Man-B }}\right)$, 87.05, 84.09, 83.19, 81.29, 76.52, 75.14, 70.98, 69.98, 66.68, 66.39, 65.69, 61.16, 60.89, 38.48, 29.35, 21.19.HR ESI-TOF MS $(\mathrm{m} / \mathrm{z})$ : calcd for $\mathrm{C}_{25} \mathrm{H}_{45} \mathrm{NO}_{19} \mathrm{H}[\mathrm{M}+\mathrm{H}]^{+}, 664.2664$; found 664.2657

\section{Acknowledgements}

We thank the China Scholarship Council (CSC) for Ph.D. fellowships to Zhihao LI and Changping ZHENG. Financial supports from the Centre National de la Recherche Scientifique (CNRS) and the Sorbonne Université in France are gratefully acknowledged.

\section{References}

[1] Global Tuberculosis Report 2019, 2019, https://www.who.int/tb/publications/global report/en/

[2] a) M. Joe, D. Sun, H. Taha, G. C. Completo, J. E. Croudace, D. A. Lammas, G. S. Besra, T. L. Lowary, J. Am. Chem. Soc. 2006, 128, 5059-5072; b) L. Wang, S. Feng, L. An, G. Gu, Z. Guo, J. Org. Chem. 2015, 80, 10060-10075.

[3] P. Andersen, T. M. Doherty, Nat. Rev. Microbiol. 2005, 3, 656.

[4] a) J. W. Dennis, M. Granovsky, C. E. Warren, Biochim. Biophys. Acta, Gen. Subj. 1999, 1473, 21-34; b) K. Kato, A. Ishiwa;cA. Weintraub, Carbohydr. Res. 2003, 338, 2539-2547.

[5] A. Hölemann, B. L. Stocker, P. H. Seeberger, J. Org. Chem. 2006, 71, 8071-8088.

[6] Z. Li, C. Zheng, M. Terreni, L. Tanzi, M. Sollogoub, Y. Zhang, Curr. Med. Chem. 2019.

[7] D. R. Bundle, P.-H. Tam, H.-A. Tran, E. Paszkiewicz, J. Cartmell, J. M. Sadowska, S. Sarkar, M. Joe, P. I. Kitov, Bioconjug. Chem. 2014, 25, 685-697. 
[8] J. Gao, G. Liao, L. Wang, Z. Guo, Org. Lett. 2014, 16, 988-991.

[9] C. Wattanasiri, J. Paha, M. Ponpuak, S. Ruchirawat, S. Boonyarattanakalin, Carbohydr. Polym. 2017, 175, 746-755

[10] T. Bavaro, S. Tengattini, L. Piubelli, F. Mangione, R. Bernardini, V. Monzillo, S. Calarota, P. Marone, M. Amicosante, L. Pollegioni, Molecules 2017, 22, 1081.

[11] a) S. S. Gupta, J. Kuzelka, P. Singh, W. G. Lewis, M. Manchester, M. Finn, Bioconjug. Chem. 2005, 16, 1572-1579; b) T. Bavaro, M. Filice, C. Temporini, S. Tengattini, I. Serra, C. F. Morelli, G. Massolini, M. Terreni, RSC Adv. 2014, 4, 56455-56465.

[12] Y. Su, J. Xie, Y. Wang, X. Hu, X. Lin, Eur. J. Med. Chem. 2010, 45, 2713-2718.

[13] S. J. Jun, M. S. Moon, S. H. Lee, C. S. Cheong, K. S. Kim, Tetrahedron Lett. 2005, 46, 5063-5065.

[14] M. K. Gurjar, L. K. Reddy, S. Hotha, J. Org. Chem. 2001, 66, 4657-4660.

[15] S. R. Lu, Y. H. Lai, J. H. Chen, C. Y. Liu, K. K. T. Mong, Angew. Chem., Int. Ed. Engl. 2011, 50, 7315-7320.

[16] C. S. Chao, C. Y. Lin, S. Mulani, W. C. Hung, K. k. T. Mong, Chem. - Eur. J. 2011, 17, 12193-12202.

\section{Graphical Abstract}
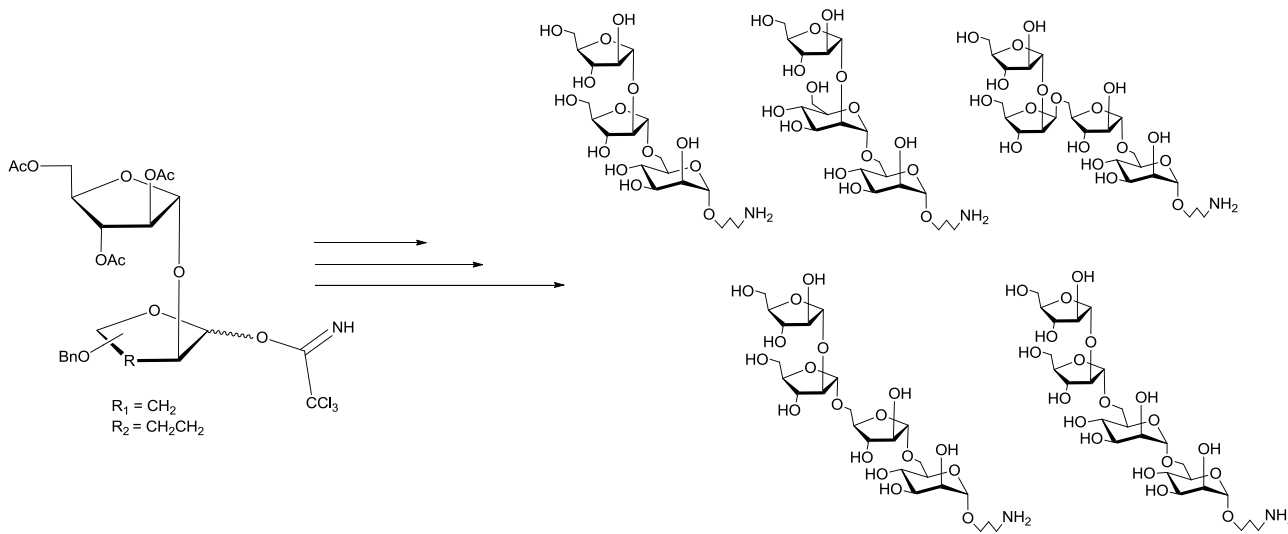

A convenient synthesis of oligosaccharides derived from lipoarabinomannan (LAM) with glycosyl donors having a nonparticipating group at C2 was achieved from top to bottom. Different donors and acceptors were compared to make the stereoselective construction of glycosidic bonds. Five LAM analogues were obtained with amino group which can be used for conjugation with proteins. 